\title{
Geochronology, geochemistry and tectonic significance of a Paleoproterozoic diabase at southwestern margin of the NCC
}

\author{
Huan $\mathrm{Xu}^{1,2}$, Jin-hai Luo ${ }^{1, *}$, Guan-xu Chen ${ }^{1,3}$, Jia You ${ }^{4}$, and Yi-fei $\mathrm{Li}^{1}$ \\ ${ }^{1}$ State Key Laboratory of Continental Dynamics, Department of Geology, Northwest University, Xi'an, China \\ ${ }^{2}$ Shaanxi Railway Institute, Department of Surveying and Mapping Engineering, Weinan, Shaanxi, China \\ ${ }^{3}$ Yuncheng University, Department of Culture and Tourism, Yuncheng, Shanxi, China \\ ${ }^{4}$ The Second Oil Production Plant of Changqing Oilfield Company, Qingyang, Gansu, China
}

\section{Article history:}

Received 18 July 2018

Revised 21 April 2019

Accepted 27 May 2019

\section{Keywords:}

Southwestern margin of the North China Craton, Paleoproterozoic, Diabase, Mantle plume, Intracontinental rifting

\section{Citation:}

Xu, H., J. Luo, G. Chen, J. You, and Y. Li, 2019: Geochronology, geochemistry and tectonic significance of a Paleoproterozoic diabase at southwestern margin of the NCC. Terr. Atmos. Ocean. Sci., 30, 771-791, doi: 10.3319/TAO.2019.05.27.02

\begin{abstract}
The diabase and granite porphyry outcrop in the Baijiagou section within the Meso-Cenozoic Liupanshan fault zone at the southwestern margin of the North China Craton (NCC), and they have been regarded previously as Meso-Cenozoic dykes according to their occurrence. Zircon U-Pb LA-ICP-MS age determining for the diabase and granite porphyry yield respectively $1804 \pm 21$ and $1792 \pm 16 \mathrm{Ma}$, and they form a bimodal magmatic assemblage of Paleoproterozoic. The diabase can be classified into two major geochemical types, which are low-Ti (LT) and high-Ti (HT) in nature. The former is characterized by relatively high $\mathrm{SiO}_{2}(48.81-54.01$ wt.\%), $\mathrm{P}_{2} \mathrm{O}_{5}$, and $\mathrm{Al}_{2} \mathrm{O}_{3}$, and low $\mathrm{TiO}_{2}$ (1.41 - 1.54 wt.\%), $\mathrm{FeO}, \mathrm{MnO}$, and $\mathrm{CaO}$, and enriched whole-rock $\mathrm{Sr}$ and $\mathrm{Nd}$ isotopic composition $\left[\left({ }^{87} \mathrm{Sr} /{ }^{86} \mathrm{Sr}\right)_{i}=0.703-0.708 ; \varepsilon_{\mathrm{Nd}}=-3.76\right.$ to -4.37]. The latter has lower $\mathrm{SiO}_{2}$ (45.9 - 51.19 wt.\%), $\mathrm{P}_{2} \mathrm{O}_{5}$, and $\mathrm{Al}_{2} \mathrm{O}_{3}$, and higher $\mathrm{TiO}_{2}(1.61-2.26 \mathrm{wt} . \%)$ and $\mathrm{FeO}$ than that of the former, and depleted $\mathrm{Sr}$ and $\mathrm{Nd}$ isotopic composition $\left.\left[{ }^{87} \mathrm{Sr} /{ }^{86} \mathrm{Sr}\right)_{i}=0.691-0.708 ; \varepsilon_{\mathrm{Nd}}=3.27-5.03\right]$. Both types of diabase exhibit light rare earth element enrichment and flat middle-heavy rare earth element patterns. The LT diabase has negative Eu anomalies and higher total REE contents than the HT diabase. $\mathrm{Th} / \mathrm{Nb}$ ratios of the LT and HT diabases are $0.28-0.29$ and $0.08-0.10$, respectively, which are similar to basalts formed in an intraplate spreading setting in association with a mantle plume. The regional geology suggests that intracontinental rifting occurred at the southwestern margin of the NCC in the Paleoproterozoic, and that the rifting was related to a mantle plume. This rifting event was part of the break-up of the Columbia supercontinent.
\end{abstract}

\section{INTRODUCTION}

The North China Craton (NCC) includes a history that are up to $4.0 \mathrm{Ga}$ old and most of the rocks in the NCC formed at $3.0-2.5 \mathrm{Ga}$ (Zhu et al. 2012), making it one of the oldest cratons in the world. During the late Paleoproterozoic and early Mesoproterozoic orogenesis, uplift, and extension happened to the NCC (Zhai and Santosh 2011, 2013; Zhai et al. 2014). The NCC is divided into eastern and western blocks, separated from each other by the Central Orogenic Belt, which formed prior to $1.85 \mathrm{Ga}$ (Zhao et al. 2005; Jiang et al. 2010). The western block comprises the Yinshan and Ordos blocks (Zhao et al. 2005), which amalgamated at $\sim 1.95 \mathrm{Ga}$ (Li et al.

\footnotetext{
* Corresponding author

E-mail:luojh@nwu.edu.cn
}

2013). After $1.8 \mathrm{Ga}$, a mantle plume caused uplift and extension in the NCC, resulting in rifting and the development of the Helan, Xiong'er, and Yanshan-Taihang aulacogens (Li et al. 2000; Zhao et al. 2007; Gao et al. 2013). Late Paleoproterozoic and Mesoproterozoic rifting was accompanied by extensive magmatism, including extrusion of the Xiong'er Group volcanic rocks (1.80 - $1.75 \mathrm{Ga}$; Zhao et al. 2004; Xu et al. 2007) and intrusion of coeval granodiorites and porphyries (Zhao et al. 2007; Cui et al. 2010), mafic dike swarms of the Xiong'er aulacogen (Hou et al. 2010), and mafic dike swarms and alkaline intrusive rocks of the Yanshan-Taihang aulacogen (1.77 - 1.78 Ga; Peng et al. 2004; Yang et al. 2005; Dong et al. 2010). The distribution of Paleoproterozoic magmatic rocks in the North China Craton is shown as Fig. 1, 
and the related data are in Table 1. The late Paleoproterozoic extension event has been extensively studied, although the mechanisms driving the extension are not well understood. Peng et al. (2008) and Zhai et al. (2014) argued that extension was related to mantle plume activity, and speculated that the southern margin of the NCC (Xiong'er Group volcanic rocks) was the locus of the mantle plume.

The Proterozoic geology of the southern part of the Helanshan and Liupanshan Mountains in this Paleoproterozoic aulacogen is obscured by Meso-Cenozoic metasedimentary strata and the reactivation of the Liupanshan fault system. This has limited our understanding of the Paleoproterozoic and Mesoproterozoic tectonic framework in this region (Che et al. 2011). The Helan aulacogen has been identified at the western margin of the NCC using seismic data, and also from sedimentological observations in the northern part of the Helanshan area. Seismic profiles have revealed a series of extensional faults in the Proterozoic successions, indicating that the 4000-5000-m-thick Mesoproterozoic strata were controlled by syn-sedimentary faulting (Wang 1995; Hua and Qiu 2001). Similar lithological and tectonic characteristics have been identified in the Yanliao aulacogen (Wang 1995; Hua and Qiu 2001; Gao et al. 2010). The limited study of Paleoproterozoic igneous rocks at the southwestern and western margins of the NCC is a barrier to improving our understanding of the evolution of the NCC. Here we present petrological, geochronological, and geochemical data for the Baijiagou diabase and granite porphyry from the southwestern margin of the NCC. We use these data to constrain the petrogenesis and tectonic setting in which the diabase was emplaced, and show that extensional tectonism affected the NCC and formation of the Helan aulacogen in the Paleoproterozoic.

\section{REGIONAL GEOLOGY}

The Helan aulacogen trends approximately N-S and forms a valley located between the Erdos and Alxa blocks at the western margin of the NCC. During the Proterozoic, the Helan aulacogen extended into the NCC and was filled with littoral clastic sediments and carbonates. The sediments are $\sim 1000 \mathrm{~m}$ thick and were overlain by sediments of the south Qilin Trough in the Late Ordovician (Che et al. 2011). Geochronological studies of khondalite-series rocks in the northern Helan Mountains have yielded metamorphic ages of 1.9 - 2.1 Ga (Geng et al. 2010; Zhou et al. 2010; Xiao et al. 2011). The khondalite rocks are the product of Paleoproterozoic crustal development, and intrusive rocks in this area yield emplacement ages of ca. $1.85 \mathrm{Ga}$ (Geng et al. 2010); however, igneous rocks are poorly exposed in the southern part of the Helan aulacogen.

The Baijiagou diabase and associated granite porphyry are exposed in Longxian Country, Shaanxi Province (Fig. 2). The bimodal magmatism potentially provides im- portant insights into the Paleoproterozoic geological evolution of the NCC. Based on contact relationships between the intrusive and country rocks, Che and Wang (1985) suggested that the Baijiagou diabase and granite porphyry are Late Cretaceous to early Paleogene in age, and concluded that their formation was associated with the Liupanshan fault system. The 1:50000 scale geological map of Guguan Town (1996) followed the findings of Che and Wang (1985), and assigned the diabase and granite porphyry a Paleogene age. Our field observations indicate that the sedimentary strata in the study area are Upper Ordovician clastic limestones, Upper Triassic clastic sediments, Lower Cretaceous sandstones, and Quaternary sediments. Faults are widely developed. The contacts between the intrusive and country rocks are generally covered by Quaternary sediments; however, it is clear that metamorphism did not affect the Upper Ordovician limestones. You et al. (2014) obtained an upper intercept $\mathrm{U}-\mathrm{Pb}$ zircon age of $1846 \pm 32 \mathrm{Ma}$ for the Baijiagou granite porphyry, indicating that it was emplaced during the Paleoproterozoic, whereas the diabase has not yet been dated.

\section{PETROGRAPHY}

There are only a few small outcrops $\left(<20 \mathrm{~m}^{2}\right)$ of diabase and granite porphyry in the Baijiagou area, which have been exposed by river erosion. In almost all outcrops, the relationship between the granite porphyry and diabase is evident (Figs. 3a-c). The diabase is in direct contact with the granite porphyry, and the latter contains diabase xenoliths (Fig. 3b). In addition, granite porphyry veins have intruded into the diabase (Fig. 3c). The diabase samples are greyish green in color (Fig. 3a), massive in structure, and have ophitic textures (Figs. 3d, e). The diabase phenocrysts are predominantly calcic plagioclase and pyroxene, and comprise $\sim 70 \%$ of the rock. The plagioclase (40\%) is idiomorphic and weakly altered. Some plagioclase crystals display simple and polysynthetic twinning. Pyroxenes (30\%) are allotriomorphic and infill space between the plagioclase crystals. The pyroxene is locally replaced by mica minerals. Secondary minerals are hornblende and biotite (15\%), which are allotriomorphic. The main accessory mineral is magnetite.

The granite porphyry samples are red in color and have a porphyritic texture (Fig. 3f). Phenocrysts are predominantly K-feldspar (25\%). The feldspar is altered and occasionally exhibits simple and polysynthetic twinning. Quartz phenocrysts comprise $20 \%$ of the rock, and are unaltered with corroded and embayed edges. Plagioclase is weakly altered and comprises $10 \%$ of the rock. Secondary biotite is present and the matrix is aphanitic or microcrystalline, comprising feldspar and quartz.

We have collected twelve samples for both of the diabase and granite porphyry, ten of which are for geochemical analysis, one is for chronological analysis, and one is for petrographic analysis. 


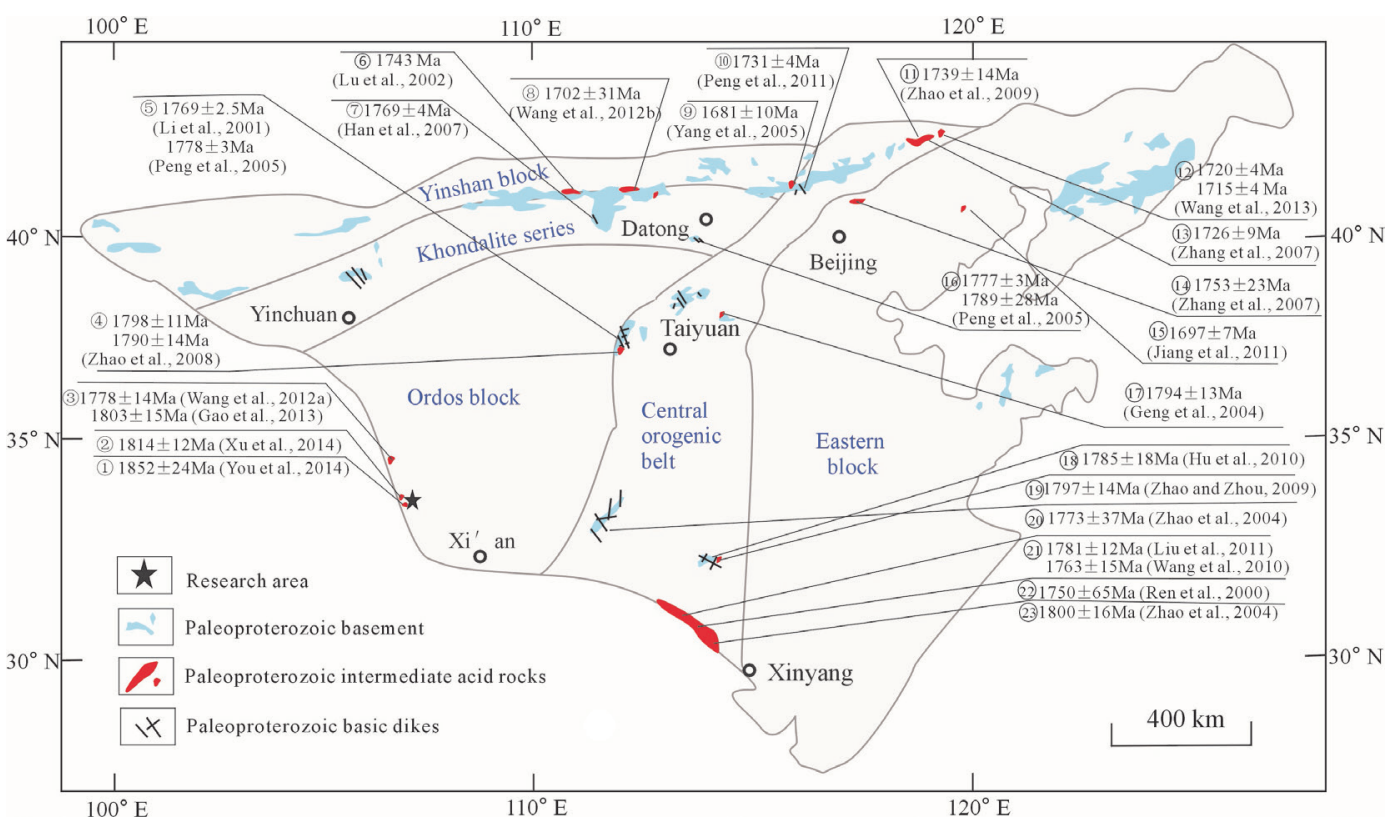

Fig. 1. Paleoproterozoic magmatic rocks distribution diagram in the North China Craton (after Zhao et al. 2015).

Table 1. Magmatic rocks of Paleoproterozoic in the North Chian Craton.

\begin{tabular}{|c|c|c|c|c|}
\hline Position & Rock type & Method & Age (Ma) & Reference \\
\hline (1) Baijiagou & granite porphyry & U-Pb LA-ICP-MS & $1852 \pm 24$ & You et al. 2014 \\
\hline (2) Tiemahe & granite porphyry & U-Pb LA-ICP-MS & $1814 \pm 12$ & Xu et al. 2014 \\
\hline \multirow[t]{2}{*}{ (3) Shizuizi } & granite porphyry & SHRIMP & $1778 \pm 14$ & Wang et al. 2012a \\
\hline & & U-Pb LA-ICP-MS & $1803 \pm 15$ & Gao et al. 2013 \\
\hline (4) Guandishan & granite & SHRIMP & $1798 \pm 11$ & Zhao et al. 2008 \\
\hline Tangershang & granite & SHRIMP & $1790 \pm 14$ & \\
\hline \multirow[t]{2}{*}{ (5) Hengshan } & basic dike & U-Pb LA-ICP-MS & $1769 \pm 2.5$ & Li et al. 2001 \\
\hline & & SHRIMP & $1778 \pm 3$ & Peng et al. 2005 \\
\hline (6) Baiyan obo & basalt & U-Pb LA-ICP-MS & 1743 & Lu et al. 2002 \\
\hline (7) Fengzhen & basic dike & SHRIMP & $1769 \pm 4$ & Han et al. 2007 \\
\hline (8) Guyang & quartz syenite & U-Pb LA-ICP-MS & $1702 \pm 31$ & Wang et al. 2012b \\
\hline (9) Miyun & rapakivi granite & U-Pb LA-ICP-MS & $1681 \pm 10$ & Yang et al. 2005 \\
\hline (10) Miyun & basic dike & SHRIMP & $1731 \pm 4$ & Peng et al. 2011 \\
\hline (11) Damiao & monzonite & SHRIMP & $1739 \pm 14$ & Zhao et al. 2009 \\
\hline \multirow[t]{2}{*}{ (12) Jianping } & clinopyroxene monzonite & U-Pb LA-ICP-MS & $1720 \pm 4$ & Wang et al. 2013 \\
\hline & quartz syenite & U-Pb LA-ICP-MS & $1715 \pm 4$ & \\
\hline (13) Damiao & anorthosite & U-Pb LA-ICP-MS & $1726 \pm 9$ & Zhang et al. 2007 \\
\hline (14) Beigukou & syengranite & U-Pb LA-ICP-MS & $1753 \pm 23$ & Zhang et al. 2007 \\
\hline (15) Chicheng & rapakivi granite & U-Pb LA-ICP-MS & $1697 \pm 7$ & Jiang et al. 2011 \\
\hline \multirow[t]{2}{*}{ (16) Datong } & basic dike & SHRIMP & $1777 \pm 3$ & Peng et al. 2005 \\
\hline & & SHRIMP & $1789 \pm 28$ & \\
\hline (17) Luyashan & adamellite & U-Pb LA-ICP-MS & $1794 \pm 13$ & Geng et al. 2004 \\
\hline (18) Songshan & basic dike & SHRIMP & $1785 \pm 18$ & Hu et al. 2010 \\
\hline (19) Motianzhai & granite & SHRIMP & $1797 \pm 14$ & Zhao and Zhou 2009 \\
\hline (20) Xiong'ershan & basic dike & SHRIMP & $1773 \pm 37$ & Zhao et al. 2004 \\
\hline \multirow[t]{2}{*}{ (21) Xiong'ershan } & subvolcanics & U-Pb LA-ICP-MS & $1781 \pm 12$ & Liu 2011 \\
\hline & rhyolite & U-Pb LA-ICP-MS & $1763 \pm 15$ & Wang et al. 2010 \\
\hline (22) Xiong'ershan & syenite & U-Pb LA-ICP-MS & $1750 \pm 65$ & Ren et al. 2000 \\
\hline (23) Xiong'ershan & rhyolite porphyry & U-Pb LA-ICP-MS & $1800 \pm 16$ & Zhao et al. 2004 \\
\hline
\end{tabular}




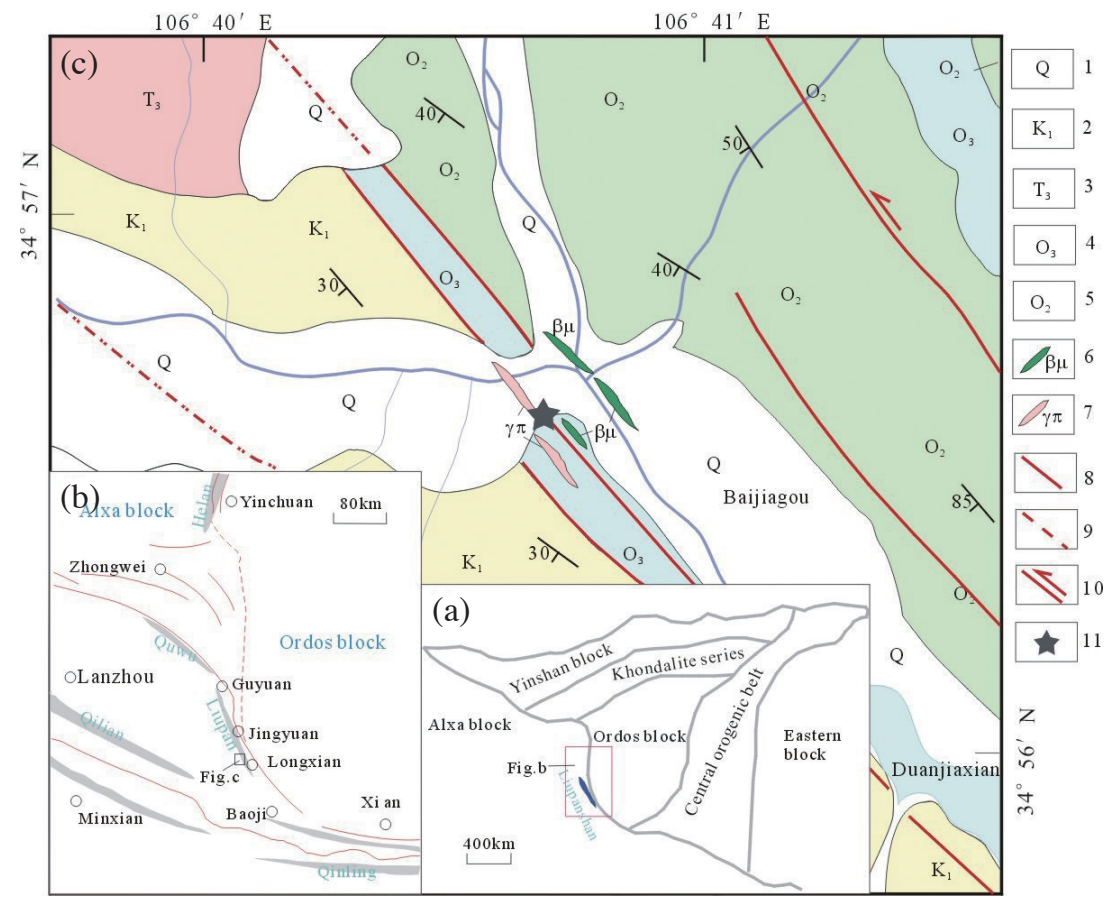

Fig. 2. Geological map of the Baijiagou region in Longxian (modified after the 1:50000 Geological Map of Guguan). 1: Quaternary sediments; 2: Lower Cretaceous sandstone; 3: Upper Triassic sandstone; 4: Upper Ordovician limestone; 5: Middle Ordovician limestone; 6: diabase; 7: granite; 8: fault; 9: inferred fault; 10: sinistral strike-slip fault; 11: sample locality.
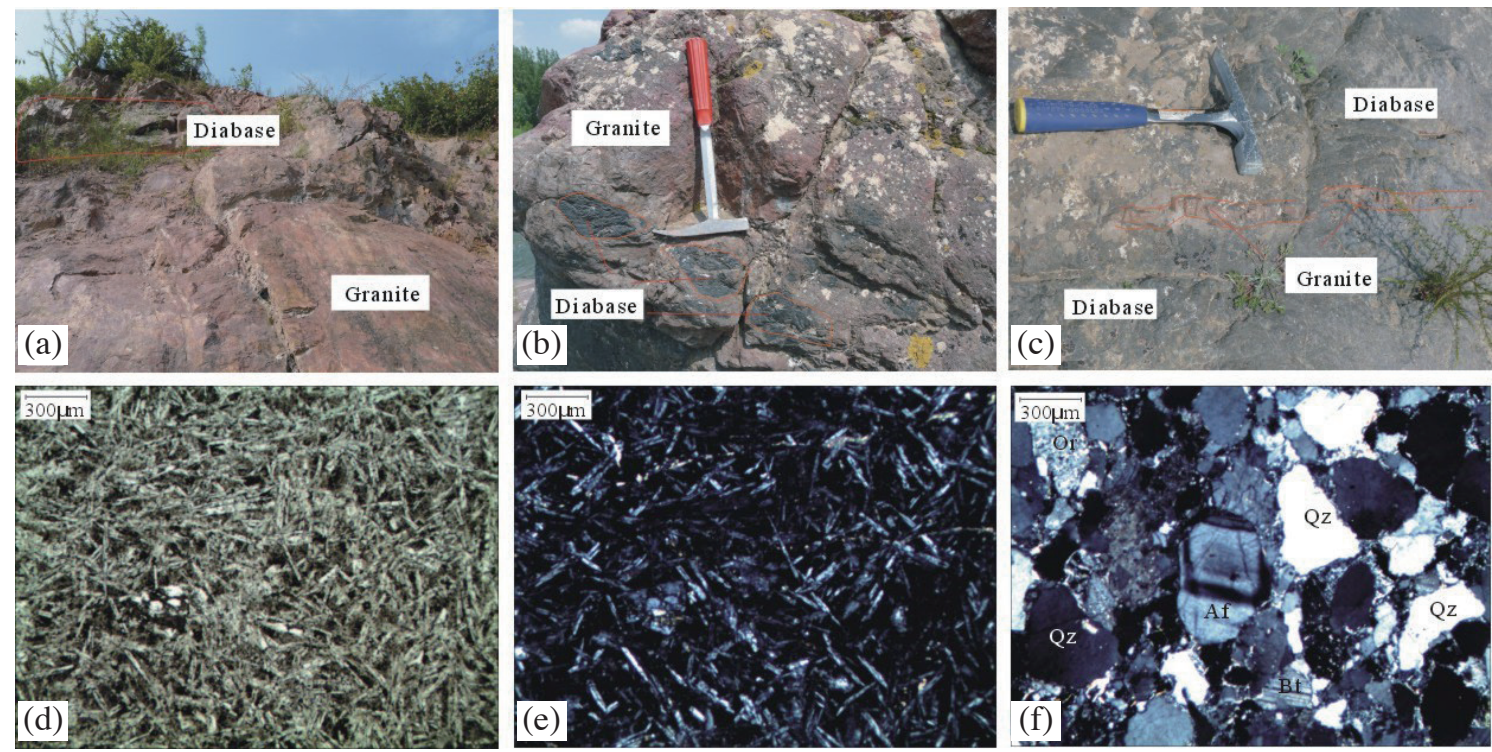

Fig. 3. (a) (b) (c) Field contacts between the diabase and granite porphyry; (d) (e) microphotographs of the diabase; (f) microphotograph of the granite porphyry. Af = alkali feldspar; $\mathrm{Bt}=$ biotite; Or = orthoclase; $\mathrm{Qz}=$ quartz . 


\section{ANALYTICAL METHODS}

All analyses were performed at the State Key Laboratory of Continental Dynamics, Northwest University, Xi'an, China.

\subsection{Zircon U-Pb LA-ICP-MS Analysis}

Zircons were separated using heavy liquid and magnetic separation techniques, and then handpicked under a binocular microscope. The selected grains were mounted in epoxy resin and polished until their crystal centers were exposed. Cathodoluminescence (CL) images showing the internal structure of the zircon grains were captured using a Quanta 400FEG environmental scanning electron microscope, equipped with an Oxford energy dispersive spectroscopy system and a Gatan CL3+ detector.

$\mathrm{U}-\mathrm{Pb}$ dating of zircons was conducted with an Agilent 7500a inductively coupled plasma-mass spectrometer (ICP-MS) coupled to a $193 \mathrm{~nm}$ ArF excimer laser, flow homogenizer, and optical imaging system. A fixed spot size of $30 \mu \mathrm{m}$ and laser repetition rate of $6 \mathrm{~Hz}$ were used for all analyses. Helium was used as the carrier gas to provide efficient aerosol delivery to the plasma ion source. The National Institute of Standards and Technology (NIST) Standard Reference Material (SRM) 610 was used to optimize the instrument to maximize sensitivity (238U signal intensity of $\left.>460 \mathrm{cps} / \mu \mathrm{g} \cdot \mathrm{g}^{-1}\right)$ and minimize oxide production $(\mathrm{ThO} /$ $\mathrm{Th}<1 \%$ ). The U/Th ratio was used to monitor whether zircon vaporization was complete (Günther and Hattendorf 2005). Analyses were made in time-resolved mode using both analog and pulsed detection, and fast peak jumping $\left(20 \mathrm{~ms} \mathrm{peak}^{-1}\right)$. GLITTER 4.0 software developed by Macquarie University was used to calculate ${ }^{207} \mathrm{~Pb} /{ }^{206} \mathrm{~Pb}$, ${ }^{206} \mathrm{~Pb} /{ }^{238} \mathrm{U},{ }^{207} \mathrm{~Pb} /{ }^{235} \mathrm{U}$, and ${ }^{208} \mathrm{~Pb} /{ }^{232} \mathrm{Th}$ ratios, which were corrected for instrumental mass bias and depth-dependent elemental and isotopic fractionation using the 91500 zircon as an external standard (recommended ${ }^{206} \mathrm{~Pb} /{ }^{238} \mathrm{U}$ age of 1065.4 $\pm 0.6 \mathrm{Ma}$; Wiedenbeck et al. 2004). Concordia diagrams and weighted mean age calculations were made using Isoplot (v. 2.49; Ludwig 2001). U, Th, and Pb concentrations were calculated using ${ }^{29} \mathrm{Si}$ as an internal standard and NIST SRM610 as an external standard. The zircon standards 91500 and GJ-1 yielded weighted mean ${ }^{206} \mathrm{~Pb} /{ }^{238} \mathrm{U}$ ages of $1064.4 \pm 3.1$ Ma $(\mathrm{n}=16 ; 2 \sigma)$ and $603.1 \pm 3.2 \mathrm{Ma}(\mathrm{n}=14 ; 2 \sigma)$, respectively, which are in good agreement with the recommended isotope dilution-thermal ionization mass spectrometry (IDTIMS) ages reported by Wiedenbeck et al. (1995).

\subsection{Whole-Rock Major and Trace Element Analyses}

Altered surfaces were removed from selected samples prior to sample preparation for geochemical analysis. The samples were then washed, dried, and crushed to 60 mesh size in an alumina jaw crusher. Approximately $60 \mathrm{~g}$ of each crushed sample was milled in a tungsten carbide mill (T1100 ; CMT) to $<200$ mesh $(75 \mu \mathrm{m})$ for analysis.

Major element contents were determined by X-ray fluorescence (XRF; Rigaku RIX 2100) spectrometry on Liborate glass discs. Trace elements were measured using an Agilent 7500a ICP-MS after $50 \mathrm{mg}$ samples had been dissolved in sealed high-temperature and high-pressure bombs using equal volumes of ultrapure $\mathrm{HF}$ and $\mathrm{HNO}_{3}$. Analyses of United States Geological Survey (USGS) rock standards BHVO-2 and AGV-2 indicate that the accuracy and precision of the XRF and ICP-MS data were better than 5\%.

\subsection{Rb-Sr and Sm-Nd Isotope Analyses of Whole Rock}

Whole rock $\mathrm{Rb}-\mathrm{Sr}$ and $\mathrm{Sm}-\mathrm{Nd}$ isotope ratios were determined using a Micromass MC-ICP-MS Nu Plasma HR. Separation of $\mathrm{Sr}$ and $\mathrm{Nd}$ was done by using a routine twocolumnion ion-exchange technique. Isotopic ratios were measured on Isoprobe mass spectrometer in a static mode. During our analyses, ${ }^{143} \mathrm{Nd} /{ }^{144} \mathrm{Nd}$ ratios of $0.512120 \pm 12$ $(2 \sigma)$ were obtained for the international standard Shin Etou JNdi-1 and ${ }^{87} \mathrm{Sr} /{ }^{86} \mathrm{Sr}$ ratios of $0.710247 \pm 17(2 \sigma)$ for the international standard NBS-987. Correction of isotopic mass fractionation for $\mathrm{Nd}$ and $\mathrm{Sr}$ were made with ${ }^{146} \mathrm{Nd} /{ }^{144} \mathrm{Nd}=$ 0.7219 and ${ }^{86} \mathrm{Sr} /{ }^{88} \mathrm{Sr}=0.1194$, respectively (Wei et al. 2002; Liang et al. 2003).

\section{RESULTS}

\subsection{Zircon U-Pb Geochronology}

Zircon U-Pb dating was carried out on diabase sample 12LX26 (Table 2) and granite porphyry sample 14LP15 (Table 3). Zircons from the diabase are smaller, euhedral, short columnar in shape, darker in CL images, and have broad zoning that is not oscillatory (Fig. 4). These are interpreted to be the primary zircon from the diabase, and have high $\mathrm{U}$ and Th contents, and high $\mathrm{Th} / \mathrm{U}$ ratios $(0.28$ - 4.75) indicative of a magmatic origin (Rubatto 2001). Zircons from the granite porphyry are intermediate in size, euhedralsubhedral, columnar in shape, and exhibit oscillatory zoning (Fig. 5). The granitic zircon grains are larger than those from the diabase, and have $\mathrm{Th} / \mathrm{U}$ ratios of $0.49-1.08$, which are much higher than those of metamorphic zircon.

Twenty zircon grains from the diabase were analyzed, eleven reliable points can form an inconsistency line. From a concordia plot (Fig. 6), an upper intercept ${ }^{207} \mathrm{~Pb} /{ }^{206} \mathrm{~Pb}$ age of $1804 \pm 21 \mathrm{Ma}(\mathrm{MSWD}=0.19)$ was determined, and the weighted mean age is $1803 \pm 15 \mathrm{Ma}(\mathrm{n}=8 ; \mathrm{MSWD}=0.46)$. The two ages are the same within the error range, so the age of the upper intersection can be used to represent the crystallization age of the diabase. Forty zircon grains from the granite porphyry were analyzed and thirty nine yielded concordant or near-concordant ages (Fig. 7a), and the 
upper intercept age is $1792 \pm 16 \mathrm{Ma}$ (MSWD $=0.99)$, with a weighted main ${ }^{207} \mathrm{~Pb} /{ }^{206} \mathrm{~Pb}$ age of $1800 \pm 8 \mathrm{Ma}(\mathrm{MSWD}=$ 1.9) (Fig. 7b). Using the upper intersection age represents the crystallization age of the granite porphyry. Thus, both the diabase and granite porphyry are Paleoproterozoic in age and have identical ages when analytical uncertainties are considered.

\subsection{Major Element Geochemistry of the Baijiagou Diabase}

Major and trace element data are presented in Supplementary Table 4. Due to the high loss on ignition (LOI) values, which may reflect alteration, the analytical results were recalculated on a LOI-free basis.

The $\mathrm{TiO}_{2}, \mathrm{P}_{2} \mathrm{O}_{5}, \mathrm{Al}_{2} \mathrm{O}_{3}$, and $\mathrm{FeO}$ contents of the diabase samples allow identification of two sample types: lowTi (LT) and high-Ti (HT). The LT type is characterized by relatively high $\mathrm{SiO}_{2}$ (48.8 - 54.0 wt. \%), $\mathrm{P}_{2} \mathrm{O}_{5}(0.40-0.43$ wt.\%), and $\mathrm{Al}_{2} \mathrm{O}_{3}$ (14.4 - 16.3 wt.\%), and low $\mathrm{TiO}_{2}(1.41$ - 1.54 wt.\%), $\mathrm{FeO}^{\mathrm{T}}$ (10.1 - 11.9 wt.\%), $\mathrm{MnO}$ (0.14 - 0.15 wt.\%), and $\mathrm{CaO}$ (3.2 - 5.6 wt.\%). The HT type has lower $\mathrm{SiO}_{2}$ (45.9 - 51.2 wt.\%), $\mathrm{P}_{2} \mathrm{O}_{5}\left(0.14\right.$ - 0.20 wt.\%), and $\mathrm{Al}_{2} \mathrm{O}_{3}$ (12.2 - 14.0 wt. $\%)$, and higher $\mathrm{TiO}_{2}(1.61-2.26$ wt. $\%), \mathrm{FeO}^{\mathrm{T}}$ (12.4 - 16.1 wt.\%), $\mathrm{MnO}$ (0.11 - 0.32 wt.\%), and $\mathrm{CaO}(5.4$ - 13.3 wt.\%). The $\mathrm{K}_{2} \mathrm{O}$ contents of the two types of diabase are low (average $=1.57$ wt. $\%$ ), but $\mathrm{Na}_{2} \mathrm{O}$ contents are relatively high (average $=3.65$ wt. $\%$ ). $\mathrm{In} \mathrm{a}_{2} \mathrm{O}-\mathrm{SiO}_{2}$ diagram, data for the samples plot in the alkaline-subalkaline field (Fig. 8a). The $\mathrm{MgO} /\left(\mathrm{MgO}+\mathrm{FeO}^{\mathrm{T}}\right)$ ratios vary from $0.21-$ 0.31 , comparable to those for continental basalts (typically $<0.7$; Wilson 1989). An AFM diagram shows that the diabase rocks belong to the tholeiitic series (Fig. 8b).

\subsection{Trace Element Geochemistry of the Baijiagou Diabase}

Chondrite-normalized rare earth element (REE) patterns for the diabase samples are shown in Fig. 9 (gray line represents E-MORB). Both types of diabase are characterized by light REE enrichment, with this being most pronounced in the LT diabase. Middle to heavy REE patterns are flat for both diabase types. The LT type has a negative Eu anomaly $(\delta E u=0.76-0.90)$ and total REE abundances from $210-231 \mathrm{ppm}$. The HT type only has a slightly negative or no Eu anomaly $(\delta \mathrm{Eu}=0.82-1.10)$, with total $\mathrm{REE}$ abundances of 66 - $97 \mathrm{ppm}$.

In a mid-ocean ridge basalt (MORB)-normalized multielement (spider) diagram (Fig. 10a), the diabase samples are enriched in $\mathrm{K}, \mathrm{Rb}, \mathrm{Ba}$, Th, and Ce relative to MORB. In addition, the LT type is characterized by depletions of $\mathrm{Nb}, \mathrm{Ta}$, and $\mathrm{Ti}$ relative to the HT type. In a chondrite-normalized spider diagram (Fig. 10b), there is a significant negative $\mathrm{Sr}$ anomaly in the LT type samples. The $\mathrm{Th} / \mathrm{Nb}$ ratios of the
LT and HT diabases are $0.30-0.29$ and $0.08-0.1$, respectively, and their $\mathrm{Th} / \mathrm{Ta}$ ratios are $5.83-5.58$ and $1.33-1.65$, respectively.

\subsection{Sr-Nd Isotopic Composition}

After the analysis of major and trace element, all the samples were analyzed for $\mathrm{Rb}-\mathrm{Sr}$ and $\mathrm{Sm}-\mathrm{Nd}$ isotopes (Table 5). Initial ${ }^{87} \mathrm{Sr} /{ }^{86} \mathrm{Sr}$ and ${ }^{143} \mathrm{Nd} /{ }^{144} \mathrm{Nd}$ ratios are expressed as $I_{\mathrm{Sr}}(\mathrm{t})$ and $\varepsilon_{\mathrm{Nd}}(\mathrm{t})$ values respectively, where $\mathrm{t}$ is the age of magma crystallization. The calculated $\mathrm{Nd}$ model ages are denoted as $T_{\mathrm{DM} 1}$ relative to a depleted mantle source for single-stage evolution and as $T_{\mathrm{DM} 2}$ relative to the average continental crust for two-stage evolution (Jahn and Condie 1995). The HT type diabase shows small variations in initial $\mathrm{Nd}$ isotope ratios at $\mathrm{t}=1.8 \mathrm{Ga}, 3.27-5.03$ for $\varepsilon_{\mathrm{Nd}}(\mathrm{t})$ values, and $T_{\mathrm{DM} 2}$ of $1.96-2.06 \mathrm{Ga}$. The initial $\mathrm{Sr}$ isotope ratios shows large variations, $0.691-0.708$ for $I_{\mathrm{Sr}}(\mathrm{t})$ values. $\mathrm{Sr}$ isotope system is relatively unstable to $\mathrm{Nd}$ and the former is easily modified by later geological actions. The initial $\mathrm{Nd}$ isotope ratios at $\mathrm{t}=1.8 \mathrm{Ga}$ for the $\mathrm{LT}$ type diabase are range from -3.76 to $-4.37,0.703-0.708$ for $I_{\mathrm{Sr}}(\mathrm{t})$ values, and $T_{\mathrm{DM} 2}$ of $2.61-2.65 \mathrm{Ga}$.

\subsection{Major and Trace Element Geochemistry of the Baijiagou Granite Porphyry}

The major and trace element data for the granite porphyry are presented in Supplementary Table 6. The average $\mathrm{SiO}_{2}$ content of the granite porphyry is $70.24 \mathrm{wt} . \%$. $\mathrm{SiO}_{2}$ contents of a small number of samples are low, and may have been affected by the diabase. The average total alkalis $\left(\mathrm{K}_{2} \mathrm{O}+\mathrm{Na}_{2} \mathrm{O}\right)$ content is 5.6 wt.\%, and $\mathrm{A} / \mathrm{CNK}$ values of $0.46-1.19$ indicate that the granites are aluminous to weakly peraluminous. The granite samples are characterized by light REE enrichment and negative Eu anomalies $(\delta \mathrm{Eu}=0.44-0.51)$, and are relatively depleted in highfield-strength elements (HFSEs; e.g., $\mathrm{Nb}, \mathrm{Ta}, \mathrm{Ti}$, and $\mathrm{Hf}$ ) and enriched in large-ion lithophile elements (LILEs; e.g., $\mathrm{K}, \mathrm{Rb}$, and $\mathrm{Ba}$ ). The granites have high $\mathrm{Ga} / \mathrm{Al}$ ratios, and $10000 \times \mathrm{Ga} / \mathrm{Al}$ values ranges from $2.95-5.32$ (average $=$ 3.96), much higher than the mean values for I- and S-type granite (2.1 and 2.28, respectively) (Whalen et al. 1987). These geochemical features show that the Baijiagou granite porphyry is an A-type granite, which is consistent with the findings of You et al. (2014).

\section{DISCUSSION}

\subsection{Intrusive Age of the Baijiagou Diabase}

The age of the Baijiagou diabase was previously estimated to be Late Cretaceous to early Paleogene, as inferred from contact relationships (Che and Wang 1985). We identified direct contacts between the Baijiagou diabase and 
granite porphyry, but the contact relationships with the surrounding strata are generally covered by Quaternary sediments and/or are faulted. It is thus difficult to determine the age of the diabase according to contact relationships. In addition, the country rock (Upper Ordovician calclithite) near the diabase is deformed but not hydrothermally altered, indicating that the diabase pre-dates the Upper Ordovician. The zircon $\mathrm{U}-\mathrm{Pb}$ isotopic system has a high closure temperature and strong resistance to resetting by late-stage geological processes. Zircons from the diabase yield an upper intercept ${ }^{207} \mathrm{~Pb} /{ }^{206} \mathrm{~Pb}$ age of $1804 \pm 21 \mathrm{Ma}(\mathrm{MSWD}=0.19)$, which is within error of the age obtained on the zircons from the granite porphyry [1792 $\pm 16 \mathrm{Ma}(\mathrm{MSWD}=0.99)]$. As such, both the diabase and granite porphyry are Paleoproterozoic rocks.

The Tiemahe granite porphyry in Shaanxi province $(1814 \pm 12 \mathrm{Ma}$; Xu et al. 2014), the Shizuizi granite in Ningxia province (1778 \pm 14 and $1803 \pm 15 \mathrm{Ma}$; Wang et al. 2012a; Gao et al. 2013) and the Duanjiaxia granite porphyry (1846 $\pm 32 \mathrm{Ma}$; You et al. 2014) are exposed to the north of the present study area. Diabase and basalt associated with granite porphyry are also present in the Tiemahe rocks, but their ages are unknown. These various granites are linearly distributed along the Liupanshan fault system, and the Baijiagou diabase and granite porphyry, Tiemahe granite porphyry, and Shizuizi granite can be considered the products of the same Paleoproterozoic magmatic event, which indicates that there is an important magmatic event during Paleoproterozoic at southwestern margin of the NCC. This Paleoproterozoic igneous belt (i.e., the Helan aulacogen) along the Liupanshan fault system was partially uplifted and exposed by fault movement.

\subsection{Petrogenesis of the Baijiagou Diabase}

The mineralogical and geochemical characteristics of mafic igneous rocks are controlled by source temperaturepressure conditions and compositions, lithospheric thickness, and shallow-level processes (e.g., crystal fractionation). The Baijiagou diabase samples show geochemical variations that are further explored in this section using qualitative and quantitative approaches.

\subsubsection{Crustal Contamination}

The Baijiagou diabase can be classified into LT and HT types. It is generally believed that if the source of mantle basic magma subjected to continental crust material contamination, magma of incompatible elements such as $\mathrm{La}$ or Th will be significantly higher, relative to the $\mathrm{Zr}$ or $\mathrm{Nb}$. Therefore the ratios of $\mathrm{Zr} / \mathrm{Nb}$ and $\mathrm{Nb} / \mathrm{La}$ are used to determine the crust contamination (Xu and Qiu 2010). The $\mathrm{Nb} / \mathrm{La}$ ratios of the $\mathrm{LT}$ type diabase range from 0.22 - 0.23 (i.e., much less than 1), whereas the $\mathrm{Nb} / \mathrm{La}$ ratios of the HT type diabase range from $0.81-1.13$, similar to mantle values; the $\mathrm{Th} / \mathrm{Nb}$ rations of the LT type diabase are about 0.3 (the ration of continental crust is 0.44, Weaver 1991) and the rations of the HT type diabase range from 0.08 - 1 (the ration of mantle is $0.117-0.071$, Weaver 1991). The trace elements rations suggest that the crustal contamination influenced the LT type diabase, but not the HT type. Such contamination may reflect contributions from enriched lithospheric mantle and/ or lower crust, which resulted in LILE enrichment and HFSE depletion relative to the HT type diabase. Crustal contamination also results in higher $\mathrm{Al}_{2} \mathrm{O}_{3}$ and $\mathrm{P}_{2} \mathrm{O}_{5}$ contents.

In the process of emplacement, mantle-derived magma is contaminated by assimilation of crustal materials, and the ratios of $\mathrm{Sr}$ and $\mathrm{Nd}$ isotopes will evolve toward the crust. The $\mathrm{Nd}$ isotopic versue $\mathrm{SiO}_{2}$ and $\mathrm{La} / \mathrm{Nb}$ diagrams (Fig. 11) can identify the crustal contamination, easily. From Fig. 11, LT type diabase was obviously contaminated by the crust. According to Fig. 12, in addition to one point of the initial

Table 2. Zircon U-Pb isotope data obtained by LA-ICP-MS for diabase (12LP26) from Baijiagou.

\begin{tabular}{|c|c|c|c|c|c|c|c|c|c|c|c|c|c|c|c|c|}
\hline \multirow{3}{*}{$\begin{array}{c}\text { Spot } \\
\text { No. }\end{array}$} & \multirow{3}{*}{$\begin{array}{c}\mathbf{P b}^{*} \\
(\mathbf{p p m})\end{array}$} & \multirow{3}{*}{$\begin{array}{l}{ }^{232} \mathrm{Th} \\
\text { (ppm) }\end{array}$} & \multirow{3}{*}{$\begin{array}{c}{ }^{238} \mathbf{U} \\
(\mathbf{p p m})\end{array}$} & \multirow{3}{*}{$\mathbf{T h} / \mathbf{U}$} & \multicolumn{6}{|c|}{ Istopic ratios } & \multicolumn{6}{|c|}{ Ages/Ma } \\
\hline & & & & & \multicolumn{2}{|c|}{${ }^{207} \mathrm{~Pb} /{ }^{206} \mathrm{~Pb}$} & \multicolumn{2}{|c|}{${ }^{207} \mathbf{P b} /{ }^{235} \mathbf{U}$} & \multicolumn{2}{|c|}{${ }^{206} \mathbf{P b} /{ }^{238} \mathbf{U}$} & \multicolumn{2}{|c|}{${ }^{207} \mathrm{~Pb} /{ }^{206} \mathrm{~Pb}$} & \multicolumn{2}{|c|}{${ }^{207} \mathbf{P b} /{ }^{235} \mathbf{U}$} & \multicolumn{2}{|c|}{${ }^{206} \mathrm{~Pb} /{ }^{238} \mathrm{U}$} \\
\hline & & & & & ratios & $1 \sigma$ & ratios & $1 \sigma$ & ratios & $1 \sigma$ & ages & $1 \sigma$ & ages & 10 & ages & $1 \sigma$ \\
\hline 2 & 2703 & 1986 & 7177 & 0.28 & 0.11199 & 0.00382 & 5.28361 & & 0.342 & & 1832 & 31 & 1866 & 25 & 1896 & 25 \\
\hline 3 & 3286 & 39524 & 43497 & 0.91 & 0.12402 & 0.00274 & 4.29602 & 0.05493 & 0.2511 & 0.00254 & 1813 & 18 & 1693 & 11 & 1444 & 13 \\
\hline 4 & 1840 & 22824 & 9019 & 2.53 & 0.10967 & 0.00285 & 4.92186 & 0.09209 & 0.32533 & 0.0038 & 1794 & 18 & 1806 & 16 & 1816 & 18 \\
\hline 6 & 3802 & 50630 & 20325 & 2.49 & 0.11078 & 0.00 & 4.18513 & 0.07408 & 0.273 & & 1812 & 17 & 1671 & 15 & 1560 & 20 \\
\hline 7 & 3646 & 20737 & 8390 & 2.47 & & & 4.72388 & & & & 1797 & 23 & 1771 & 19 & 1749 & 17 \\
\hline 8 & & 2846 & 1111 & 2.56 & & & & & & & 1781 & 19 & 1674 & 16 & 1589 & 15 \\
\hline 10 & 6152 & 43198 & 24636 & 1.75 & & & & & & & 1817 & 23 & 1756 & 19 & 1705 & 19 \\
\hline 12 & 1164 & 33050 & 6964 & 4.75 & & & & & & & 1802 & 67 & 1478 & 68 & 1262 & 18 \\
\hline 14 & 2073 & 21005 & 8914 & 2.36 & & & & & & & 1806 & 35 & 1692 & 26 & 1601 & 18 \\
\hline 15 & 5366 & 28061 & 101833 & 0.28 & 0.11053 & 0.0028 & 3.56664 & 0.06285 & 0.23403 & 0.00264 & 1808 & 17 & 1542 & 14 & 1356 & 18 \\
\hline 17 & 1121 & 25140 & 15712 & 1.60 & 0.11034 & 0.00346 & 4.11476 & 0.10457 & 0.27048 & 0.00369 & 1805 & 27 & 1657 & 21 & 1543 & 19 \\
\hline
\end{tabular}


Table 3. Zircon U-Pb isotope data obtained by LA-ICP-MS for k-feldspar granite porphyry (14LP15) from Baijiagou.

\begin{tabular}{|c|c|c|c|c|c|c|c|c|c|c|c|c|c|c|c|c|}
\hline \multirow{3}{*}{$\begin{array}{l}\text { Spot } \\
\text { No. }\end{array}$} & \multirow{3}{*}{$\begin{array}{c}\mathbf{P b}^{*} \\
(\mathbf{p p m})\end{array}$} & \multirow{3}{*}{$\begin{array}{c}{ }^{232} \mathrm{Th} \\
\text { (ppm) }\end{array}$} & \multirow{3}{*}{$\begin{array}{c}{ }^{238} \mathbf{U} \\
(\mathbf{p p m})\end{array}$} & \multirow{3}{*}{$\mathbf{T h} / \mathbf{U}$} & \multicolumn{6}{|c|}{ Istopic ratios } & \multicolumn{6}{|c|}{ Ages/Ma } \\
\hline & & & & & \multicolumn{2}{|c|}{${ }^{207} \mathrm{~Pb} /{ }^{206} \mathrm{~Pb}$} & \multicolumn{2}{|c|}{${ }^{207} \mathbf{P b} /{ }^{235} \mathbf{U}$} & \multicolumn{2}{|c|}{${ }^{206} \mathrm{~Pb} /{ }^{238} \mathrm{U}$} & \multicolumn{2}{|c|}{${ }^{207} \mathrm{~Pb} /{ }^{206} \mathrm{~Pb}$} & \multicolumn{2}{|c|}{${ }^{207} \mathbf{P b} /{ }^{235} \mathbf{U}$} & \multicolumn{2}{|c|}{${ }^{206} \mathrm{~Pb} /{ }^{238} \mathrm{U}$} \\
\hline & & & & & ratios & $1 \sigma$ & ratios & $1 \sigma$ & ratios & $1 \sigma$ & ages & $1 \sigma$ & ages & $1 \sigma$ & ages & $1 \sigma$ \\
\hline 1 & 677 & 16799 & 163.46 & 1.03 & 0.11128 & 0.00256 & 4.83101 & 0.06473 & 0.31481 & 0.00309 & 1820 & 12 & 1790 & 11 & 1764 & 15 \\
\hline 2 & 30.18 & 55.96 & 72.46 & 0.77 & 0.10897 & 0.00269 & 47703 & 0.07766 & 0.31806 & 0001 & 1782 & 15 & 1781 & 14 & 1780 & 17 \\
\hline 3 & 28.81 & 51.12 & 69.53 & 0.74 & 0.10898 & 0.0027 & 4.78842 & 0.07902 & 0.31864 & 0.00344 & 1782 & 15 & 1783 & 14 & 1783 & 17 \\
\hline 4 & 13.15 & 24.95 & 31.6 & 0.79 & 0.1081 & 0.00314 & 4.71419 & 0.10626 & 0.31624 & 0.00409 & 1768 & 23 & 1770 & 19 & 1771 & 20 \\
\hline 5 & 27.52 & 33.81 & 69.6 & 0.49 & 0.11039 & 0.00272 & 4.88001 & 0.07968 & 0.32058 & 0.00345 & 1806 & 15 & 1799 & 14 & 1793 & 17 \\
\hline 6 & 44.74 & 109.41 & 107.98 & 1.01 & 0.10921 & 0.00258 & 4.58451 & 0.0672 & 0.30442 & 0.0031 & 1786 & 13 & 1746 & 12 & 1713 & 15 \\
\hline 7 & 22.70 & 43.99 & 57.26 & 0.77 & 0.10935 & 0.0029 & 4.6737 & 0.08779 & 0.30997 & 0.00356 & 1726 & 59 & 1730 & 24 & 1733 & 19 \\
\hline 8 & 23.67 & 47.83 & 62.24 & 0.77 & 10961 & 0.00301 & 4.58901 & 0.09242 & 0.30364 & 0.00363 & 1793 & 20 & 1747 & 17 & 1709 & 18 \\
\hline 9 & 29.10 & 48.68 & 72.58 & 0.67 & .11215 & 0.00278 & 4.92364 & 0.08008 & 0.31838 & & 1797 & 49 & 1786 & 20 & 1777 & 18 \\
\hline 10 & 19.24 & 43.06 & 46.21 & 0.93 & .10824 & 0.00297 & 4.66774 & 0.0941 & 0.31274 & & 1770 & 20 & 1761 & 17 & 1754 & 18 \\
\hline 11 & 18.66 & 39.26 & 46.86 & 0.84 & 11355 & 0.00314 & 4.80976 & 0.09849 & 0.30718 & & 1784 & 64 & 1748 & 27 & 1717 & 20 \\
\hline 12 & 26.05 & 47.61 & 67.84 & 0.70 & 10689 & 0.00277 & 4.48064 & 0.08058 & 0.30399 & & 1747 & 17 & 1727 & 15 & 1711 & 17 \\
\hline 13 & 26.77 & 50.59 & 65.83 & 0.77 & .10948 & 0.00281 & 4.1534 & 0.08364 & 0.31354 & & 1791 & 17 & 1773 & 15 & 1758 & 17 \\
\hline 14 & 32.93 & 56.38 & 83.79 & 0.67 & .11035 & 0.00271 & 4.74798 & 0.0759 & 0.31203 & & 1805 & 15 & 1776 & 13 & 1751 & 16 \\
\hline 15 & 18.71 & 31.73 & 47.74 & 0.66 & 0.1115 & 0.00303 & 4.78594 & 0.09491 & 0.31127 & 0.00 & 1778 & 58 & 1758 & 24 & 1741 & 19 \\
\hline 16 & 38.78 & 88.51 & 95.75 & 0.92 & 0.11174 & 0.00272 & 4.71436 & 0.0733 & 0.30596 & & 1828 & 14 & 1770 & 13 & 1721 & 16 \\
\hline 17 & 14.76 & 26.6 & 37.05 & 0.72 & 0.11134 & & 4.69946 & 0.10482 & 0.30609 & & 1768 & 66 & 1739 & 27 & 1715 & 21 \\
\hline 18 & 19.55 & 36.57 & 50.06 & 0.73 & 0.11264 & 0.00307 & 4.72404 & 0.09452 & 0.30413 & 0.00 & 1777 & 60 & 1737 & 25 & 1703 & 19 \\
\hline 19 & 41.84 & 102.12 & 100.2 & 1.02 & 0.11071 & 266 & 4.67126 & 0.07073 & 0.30597 & & 1811 & 14 & 1762 & 13 & 1721 & 16 \\
\hline 20 & 28.45 & 71.2 & 71.83 & 0.99 & 0.11219 & 0.00311 & 4.79842 & 0.09946 & 0.31016 & 0.00 & 1835 & 20 & 1785 & 17 & 1741 & 19 \\
\hline 21 & 25.06 & 46.19 & 63.29 & 0.73 & 0.11331 & 295 & 4.85338 & 0.08899 & 0.31061 & & 1853 & 17 & 1794 & 15 & 1744 & 18 \\
\hline 22 & 34.00 & 59.17 & 82.06 & 0.72 & 0.11051 & 0.00269 & 4.86001 & 0.07718 & 0.31893 & 0.0 & 1808 & 15 & 1795 & 13 & 1785 & 17 \\
\hline 23 & 23.30 & 39.51 & 58.5 & 0.68 & 0.10776 & 0.00 & 4.6317 & 0.08402 & 0.3117 & & 1762 & 17 & 1755 & 15 & 1749 & 17 \\
\hline 24 & 41.64 & 89.28 & 100.09 & 0.89 & 0.10967 & 0.00 & 4.67409 & 0.07008 & 0.30907 & 0.0 & 1794 & 14 & 1763 & 13 & 1736 & 16 \\
\hline 25 & 18.72 & 39.01 & 45.59 & 0.86 & 0.11021 & 0.0 & 4.7157 & 0.09605 & 0.31032 & 0.0 & 1803 & 20 & 1770 & 17 & 1742 & 19 \\
\hline 27 & 25.69 & 48.46 & 64.57 & 0.75 & 0.10861 & 0.00 & 4.55987 & 0.08192 & 0.30448 & 0.0 & 1776 & 17 & 1742 & 15 & 1713 & 17 \\
\hline 28 & 16.14 & 28.82 & 41.15 & 0.70 & .10948 & 0.0 & 4.55897 & 0.10371 & 0.30201 & 0.00 & 1791 & 23 & 1742 & 19 & 1701 & 19 \\
\hline 29 & 18.50 & 32.77 & 47.56 & 0.69 & 0.10878 & 0.00299 & 4.57358 & 0.09424 & 0.30492 & 0.00 & 1779 & 20 & 1744 & 17 & 1716 & 18 \\
\hline 30 & 34.51 & 69.41 & 86.88 & 0.80 & 11152 & 0.00292 & 4.64793 & 0.08722 & 0.30228 & 0.00 & 1824 & 18 & 1758 & 16 & 1703 & 17 \\
\hline 31 & 29.92 & 71.54 & 73.97 & 0.9 & 11363 & 0.00309 & 4.77757 & 0.09666 & 0.30494 & 0.00 & 1858 & 20 & 1781 & 17 & 1716 & 18 \\
\hline 32 & 31.29 & 64.23 & 72.46 & 0.89 & 10967 & 0.00273 & 4.75268 & 0.08015 & 0.31431 & 0.003 & 1794 & 16 & 1777 & 14 & 1762 & 17 \\
\hline 33 & 28.79 & 52.1 & 67.99 & 0.77 & 10951 & 0.00275 & 4.7726 & 0.08214 & 0.31609 & 0.003 & 1791 & 16 & 1780 & 14 & 1771 & 17 \\
\hline 34 & 24.67 & 42.02 & 61.89 & 0.68 & 0.10916 & 0.00284 & 4.62872 & 0.08588 & 0.30756 & 0.00356 & 1785 & 18 & 1754 & 15 & 1729 & 18 \\
\hline 35 & 37.71 & 77.88 & 96.3 & 0.81 & 0.11296 & 0.00289 & 4.70504 & 0.0842 & 0.30212 & 0.00345 & 1848 & 17 & 1768 & 15 & 1702 & 17 \\
\hline 36 & 39.90 & 106.54 & 98.66 & 1.0 & 0.10862 & 0.00278 & 4.50009 & 0.08095 & 0.30052 & 0.00341 & 1776 & 17 & 1731 & 15 & 1694 & 17 \\
\hline 37 & 26.13 & 53.38 & 60.44 & 0.88 & 0.12102 & 0.00306 & 5.08814 & 0.08941 & 0.30498 & 0.00349 & 1828 & 60 & 1756 & 25 & 1697 & 19 \\
\hline 38 & 19.68 & 36.03 & 48.63 & 0.7 & 0.11083 & 0.00302 & 4.6695 & 0.09495 & 0.30563 & 0.00375 & 1813 & 20 & 1762 & 17 & 1719 & 19 \\
\hline 39 & 21.28 & 36.41 & 52.95 & 0.69 & 0.1101 & 0.00292 & 4.64473 & 0.08983 & 0.30604 & 0.00364 & 1801 & 19 & 1757 & 16 & 1721 & 18 \\
\hline 40 & 34.60 & 62.76 & 82.04 & 0.76 & 0.11838 & 0.00286 & 5.03398 & 0.08014 & 0.3085 & 0.00335 & 1795 & 53 & 1752 & 22 & 1715 & 18 \\
\hline
\end{tabular}

Note: $\mathrm{Pb}^{*}$ represents radiogenic lead in the table. 


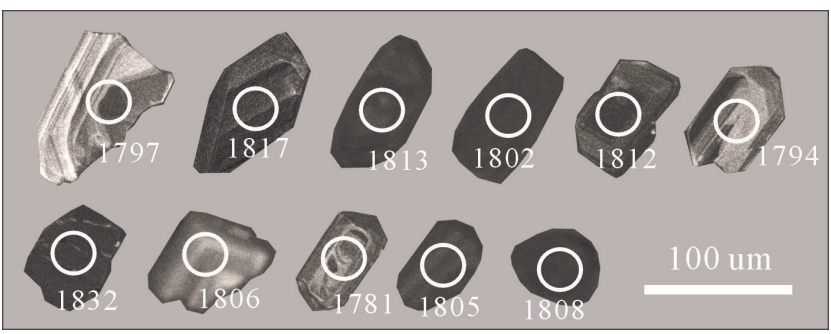

Fig. 4. Cathodoluminescence (CL) images of zircons from the Baijiagou diabase (12LP26) [the numbers in the figure stand for age (Ma) of the zircons].

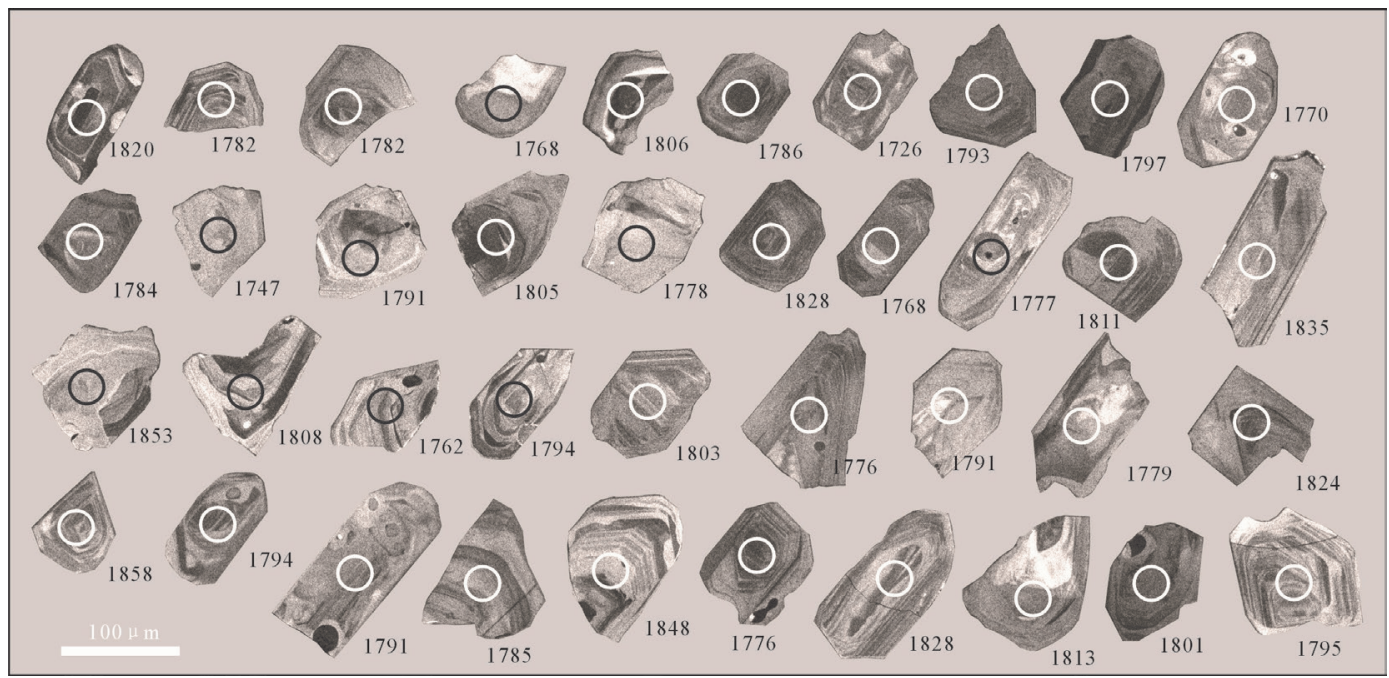

Fig. 5. Cathodoluminescence (CL) images of zircons from the Baijiagou granite porphyry (14LP15) (the numbers in the figure stand for age (Ma) of the zircons).

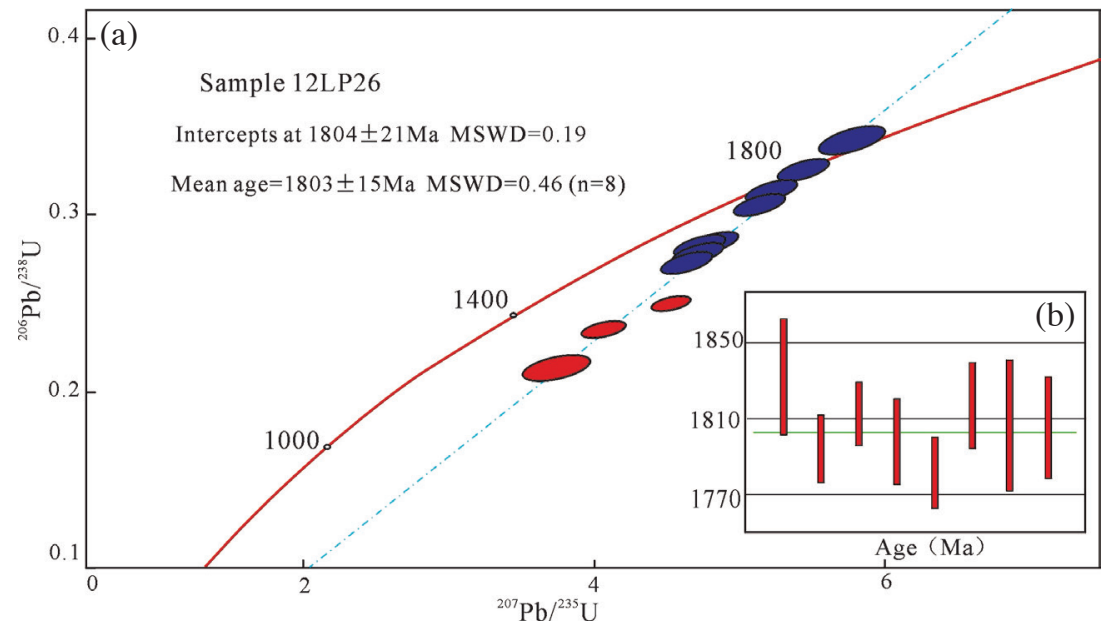

Fig. 6. U-Pb concordia diagram for zircons from the Baijiagou diabase (the blue circle in the figure is the concordia point and the red circle is inconcordia point). 
(a)

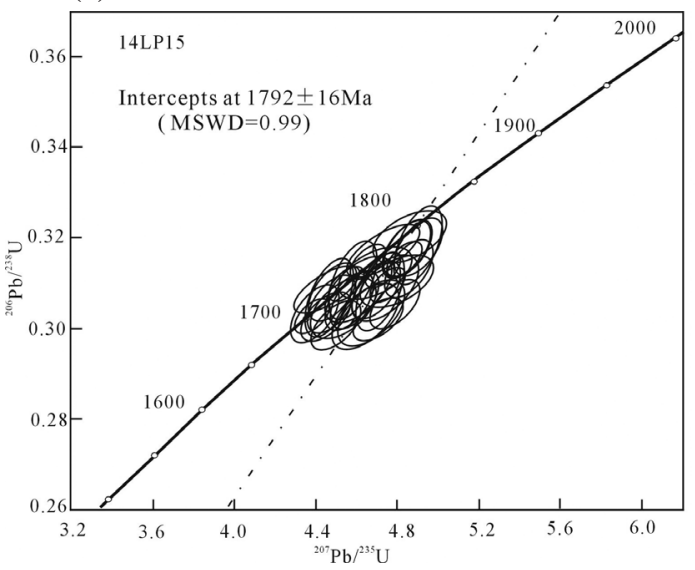

(b)

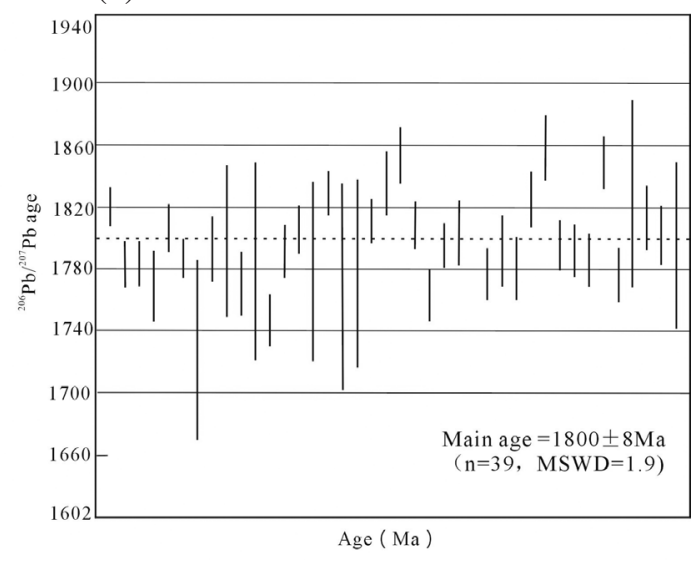

Fig. 7. U-Pb concordia diagram for zircons from the Baijiagou granite porphyry.

Table 4. Major-element (\%) and trace-element (ppm) compositions of diabase from Baijiagou.

\begin{tabular}{|c|c|c|c|c|c|c|c|c|c|c|}
\hline \multirow{2}{*}{ sample } & \multicolumn{4}{|c|}{ LT } & \multicolumn{6}{|c|}{ HT } \\
\hline & 14LP41 & 14LP43 & 14LP44 & 14LP46 & 14LP42 & 14LP45 & 14LP47 & 14LP52 & 14LP53 & 14LP54 \\
\hline $\mathrm{SiO}_{2}$ & 54.01 & 50.95 & 49.49 & 48.81 & 48.76 & 46.29 & 42.41 & 48.39 & 48.47 & 41.77 \\
\hline $\mathrm{TiO}_{2}$ & 1.47 & 1.41 & 1.54 & 1.47 & 2.12 & 2.26 & 2.04 & 1.93 & 1.88 & 1.61 \\
\hline $\mathrm{Al}_{2} \mathrm{O}_{3}$ & 14.76 & 14.37 & 16.29 & 15.08 & 13.51 & 13.31 & 13.99 & 13.91 & 12.86 & 12.23 \\
\hline $\mathrm{Fe}_{2} \mathrm{O}_{3}{ }^{\mathrm{T}}$ & 11.43 & 10.10 & 11.86 & 11.48 & 15.89 & 16.14 & 14.89 & 14.82 & 13.86 & 12.42 \\
\hline $\mathrm{MnO}$ & 0.14 & 0.15 & 0.14 & 0.15 & 0.32 & 0.19 & 0.11 & 0.22 & 0.23 & 0.28 \\
\hline $\mathrm{MgO}$ & 5.20 & 4.03 & 5.39 & 4.97 & 5.38 & 6.07 & 4.05 & 5.33 & 4.61 & 4.59 \\
\hline $\mathrm{CaO}$ & 3.51 & 5.56 & 5.05 & 5.58 & 5.37 & 7.24 & 7.92 & 6.64 & 7.48 & 13.34 \\
\hline $\mathrm{Na}_{2} \mathrm{O}$ & 3.19 & 3.97 & 3.64 & 3.62 & 4.79 & 2.91 & 4.35 & 3.92 & 3.21 & 2.91 \\
\hline $\mathrm{K}_{2} \mathrm{O}$ & 1.47 & 2.07 & 1.66 & 1.63 & 0.88 & 1.85 & 0.93 & 1.63 & 1.90 & 1.68 \\
\hline $\mathrm{P}_{2} \mathrm{O}_{5}$ & 0.41 & 0.40 & 0.43 & 0.42 & 0.20 & 0.14 & 0.20 & 0.18 & 0.18 & 0.15 \\
\hline LOI & 4.40 & 6.73 & 4.86 & 6.62 & 2.80 & 3.40 & 8.97 & 2.71 & 5.61 & 9.02 \\
\hline TOTAL & 99.99 & 99.74 & 100.35 & 99.83 & 100.02 & 99.80 & 99.86 & 99.68 & 100.29 & 100.00 \\
\hline $\mathrm{M}^{\mathrm{q} \#}$ & 51.5 & 48.2 & 51.4 & 50.2 & 44.1 & 46.7 & 38.8 & 45.6 & 43.7 & 46.3 \\
\hline $\mathrm{Li}$ & 50.1 & 27.1 & 40.3 & 36.6 & 28.1 & 34.1 & 37.1 & 30.2 & 38.0 & 31.1 \\
\hline $\mathrm{Be}$ & 1.86 & 1.13 & 1.79 & 1.88 & 2.23 & 0.73 & 1.89 & 1.37 & 2.65 & 1.83 \\
\hline $\mathrm{Sc}$ & 25.3 & 23.0 & 26.5 & 25.8 & 38.5 & 40.4 & 36.4 & 36.0 & 33.7 & 31.5 \\
\hline $\mathrm{V}$ & 154 & 131 & 156 & 159 & 375 & 542 & 355 & 360 & 324 & 343 \\
\hline $\mathrm{Cr}$ & 88.0 & 83.9 & 92.2 & 90.0 & 65.5 & 70.7 & 83.1 & 61.6 & 63.3 & 68.3 \\
\hline Co & 33.8 & 30.4 & 31.9 & 26.7 & 47.3 & 54.6 & 49.4 & 45.3 & 43.6 & 41.8 \\
\hline $\mathrm{Ni}$ & 42.7 & 38.9 & 43.9 & 42.7 & 38.0 & 49.3 & 49.0 & 36.5 & 33.9 & 41.0 \\
\hline $\mathrm{Cu}$ & 23.0 & 59.8 & 39.6 & 15.0 & 58.1 & 81.2 & 66.5 & 61.3 & 53.9 & 59.5 \\
\hline $\mathrm{Zn}$ & 217 & 131 & 139 & 135 & 179 & 130 & 206 & 130 & 123 & 117 \\
\hline $\mathrm{Ga}$ & 19.7 & 17.7 & 22.7 & 22.7 & 21.7 & 18.8 & 23.1 & 19.9 & 19.4 & 17.1 \\
\hline $\mathrm{Ge}$ & 1.50 & 1.08 & 1.55 & 1.35 & 2.03 & 2.03 & 1.30 & 1.80 & 1.69 & 2.32 \\
\hline $\mathrm{Rb}$ & 33.0 & 35.9 & 32.6 & 30.3 & 35.3 & 98.3 & 36.8 & 79.0 & 86.4 & 78.8 \\
\hline $\mathrm{Sr}$ & 363 & 266 & 515 & 341 & 207 & 254 & 238 & 206 & 214 & 260 \\
\hline $\mathrm{Y}$ & 42.3 & 38.3 & 42.7 & 41.0 & 28.2 & 21.3 & 25.7 & 25.6 & 29.4 & 25.4 \\
\hline $\mathrm{Zr}$ & 218 & 213 & 229 & 222 & 134 & 92.2 & 122 & 110 & 145 & 88.2 \\
\hline $\mathrm{Nb}$ & 9.36 & 8.96 & 9.98 & 9.57 & 14.5 & 10.1 & 13.2 & 12.5 & 13.5 & 9.55 \\
\hline
\end{tabular}

Note: $\mathrm{Fe}_{2} \mathrm{O}_{3}{ }^{\mathrm{T}}=\mathrm{FeO}+\mathrm{Fe}_{2} \mathrm{O}_{3} ; \mathrm{Mg}^{\#}=(\mathrm{MgO} / 40.31) /\left(\mathrm{MgO} / 40.31+\mathrm{Fe}_{2} \mathrm{O}_{3}{ }^{\mathrm{T}} \times 0.8998 / 71.85 \times 0.85\right) \times 100 ; \delta \mathrm{Eu}=$ $\left.w(E u)_{N} /\left\{(1 / 2)\left[w(S m)_{N}+w(G d)_{N}\right)\right]\right\}, w(E u)_{N}, w(S m)_{N}$ and $w(G d)_{N}$ are the standard values of chondrite. 
Table 4. (Continued)

\begin{tabular}{c|cccc|ccccccc}
\hline \multirow{2}{*}{ sample } & \multicolumn{7}{|c}{ LT } & \multicolumn{7}{c}{ HT } \\
\cline { 2 - 11 } & $\mathbf{1 4 L P 4 1}$ & $\mathbf{1 4 L P 4 3}$ & $\mathbf{1 4 L P 4 4}$ & $\mathbf{1 4 L P 4 6}$ & $\mathbf{1 4 L P 4 2}$ & $\mathbf{1 4 L P 4 5}$ & $\mathbf{1 4 L P 4 7}$ & $\mathbf{1 4 L P 5 2}$ & $\mathbf{1 4 L P 5 3}$ & $\mathbf{1 4 L P 5 4}$ \\
\hline $\mathrm{Cs}$ & 1.23 & 0.51 & 0.71 & 0.43 & 0.26 & 0.62 & 0.21 & 0.87 & 0.50 & 0.99 \\
$\mathrm{Ba}$ & 917 & 1289 & 1064 & 1201 & 226 & 926 & 357 & 418 & 601 & 843 \\
$\mathrm{La}$ & 42.5 & 39.3 & 43.3 & 40.9 & 13.0 & 8.93 & 14.1 & 11.4 & 13.8 & 11.8 \\
$\mathrm{Ce}$ & 89.8 & 83.9 & 92.4 & 84.9 & 32.2 & 21.6 & 33.1 & 27.0 & 33.4 & 26.0 \\
$\mathrm{Pr}$ & 11.1 & 10.3 & 11.3 & 10.5 & 4.40 & 3.09 & 4.32 & 3.83 & 4.44 & 3.61 \\
$\mathrm{Nd}$ & 44.6 & 41.2 & 45.1 & 42.5 & 19.6 & 13.9 & 18.8 & 17.2 & 19.7 & 16.1 \\
$\mathrm{Sm}$ & 8.80 & 8.06 & 8.88 & 8.39 & 4.94 & 3.66 & 4.49 & 4.41 & 4.90 & 4.07 \\
$\mathrm{Eu}$ & 2.23 & 1.91 & 2.33 & 2.37 & 1.45 & 1.30 & 1.22 & 1.46 & 1.58 & 1.51 \\
$\mathrm{Gd}$ & 8.07 & 7.37 & 8.07 & 7.72 & 5.01 & 3.79 & 4.59 & 4.56 & 5.01 & 4.31 \\
$\mathrm{~Tb}$ & 1.23 & 1.10 & 1.20 & 1.15 & 0.82 & 0.62 & 0.74 & 0.74 & 0.83 & 0.70 \\
$\mathrm{Dy}$ & 7.53 & 6.68 & 7.26 & 7.06 & 5.11 & 3.92 & 4.58 & 4.64 & 5.16 & 4.32 \\
$\mathrm{Ho}$ & 1.51 & 1.35 & 1.51 & 1.44 & 1.02 & 0.79 & 0.92 & 0.94 & 1.04 & 0.87 \\
$\mathrm{Er}$ & 4.32 & 3.94 & 4.32 & 4.14 & 2.84 & 2.19 & 2.59 & 2.61 & 2.97 & 2.40 \\
$\mathrm{Tm}$ & 0.61 & 0.58 & 0.62 & 0.60 & 0.41 & 0.32 & 0.37 & 0.37 & 0.43 & 0.33 \\
$\mathrm{Yb}$ & 4.06 & 3.84 & 4.12 & 4.03 & 2.76 & 2.04 & 2.38 & 2.45 & 2.81 & 2.14 \\
$\mathrm{Lu}$ & 0.60 & 0.58 & 0.62 & 0.60 & 0.41 & 0.31 & 0.36 & 0.36 & 0.42 & 0.32 \\
$\mathrm{Hf}$ & 5.22 & 5.01 & 5.50 & 5.25 & 3.40 & 2.32 & 3.04 & 2.78 & 3.59 & 2.21 \\
$\mathrm{Ta}$ & 0.49 & 0.47 & 0.52 & 0.49 & 0.88 & 0.61 & 0.82 & 0.75 & 0.87 & 0.59 \\
$\mathrm{~Pb}$ & 42.7 & 130 & 19.6 & 7.38 & 8.57 & 6.54 & 59.0 & 11.7 & 10.3 & 7.06 \\
$\mathrm{Th}$ & 2.78 & 2.66 & 2.89 & 2.85 & 1.27 & 0.84 & 1.31 & 0.99 & 1.44 & 0.84 \\
$\mathrm{U}$ & 0.47 & 0.43 & 0.49 & 0.55 & 0.46 & 0.35 & 0.69 & 0.39 & 0.57 & 0.34 \\
$\mathrm{SEu}$ & 0.81 & 0.76 & 0.84 & 0.90 & 0.89 & 1.06 & 0.82 & 1.00 & 0.98 & 1.10 \\
$\mathrm{NEE}$ & 227.1 & 210.0 & 230.9 & 216.3 & 93.9 & 66.4 & 92.6 & 81.9 & 96.5 & 78.6 \\
\hline & & & & & & & & & &
\end{tabular}
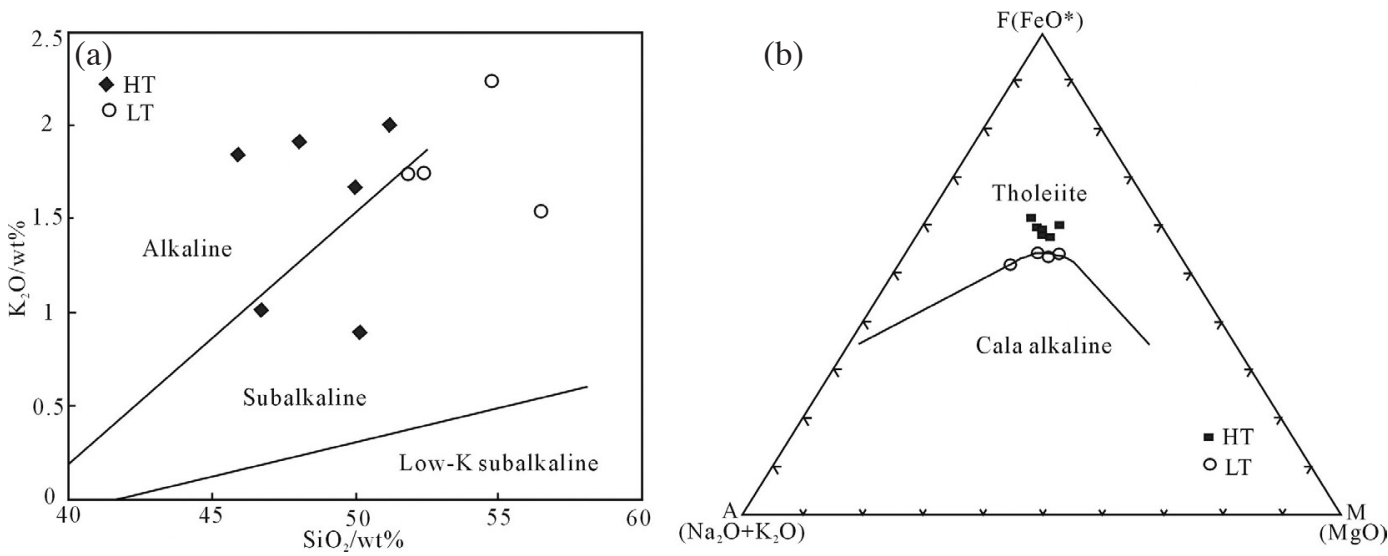

Fig. 8. (a) $\mathrm{K}_{2} \mathrm{O}-\mathrm{SiO}_{2}$ and (b) AFM discriminant diagrams (modified after Irvine and Baragar 1971) for the Baijiagou diabase. 


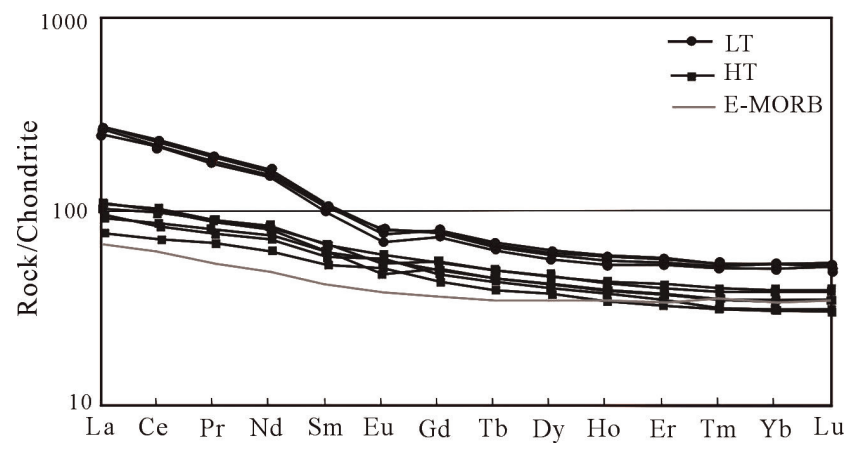

Fig. 9. Chondrite-normalized REE diagram for the Baijiagou diabase (chondrite data are from Boynton 1984).
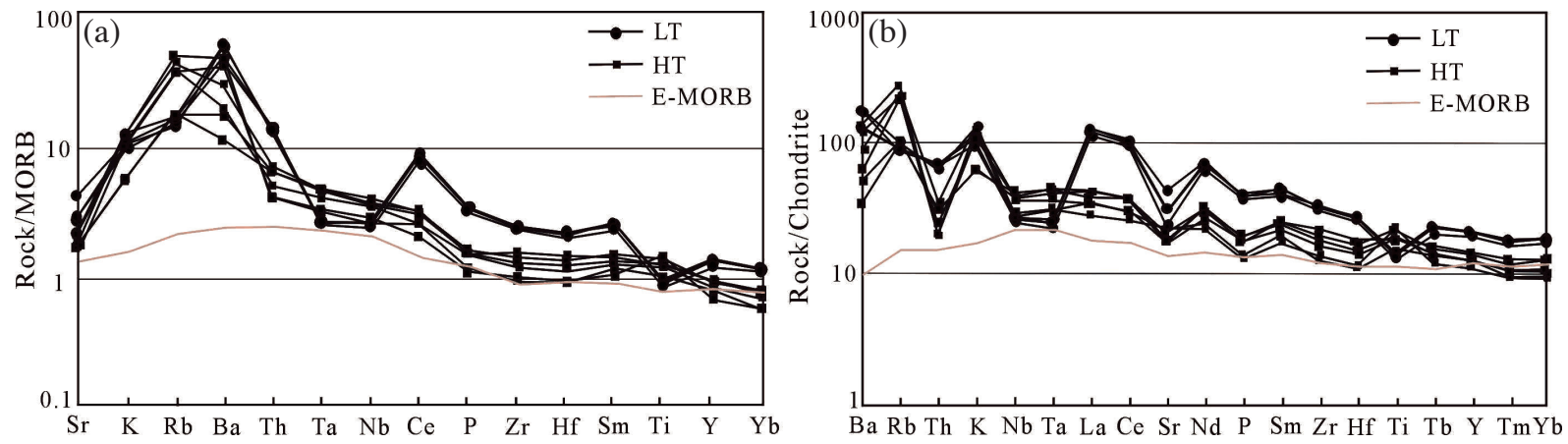

Fig. 10. Multi-element patterns for the Baijiagou diabase (MORB data are from Pearce 1982; chondrite data are from Boynton 1984).

Table 5. Sm-Nd isotopic composition of Baijiagou diabase.

\begin{tabular}{c|cccccccc}
\hline Sample & ${ }^{87} \mathbf{R b} /{ }^{86} \mathbf{S r}$ & ${ }^{87} \mathbf{S r} /{ }^{86} \mathbf{S r} \pm \mathbf{2 \sigma}$ & ${ }^{147} \mathbf{S m} /{ }^{144} \mathbf{N d}$ & ${ }^{143} \mathbf{N d} /{ }^{144} \mathbf{N d} \pm \mathbf{2 \sigma}$ & $\boldsymbol{\varepsilon}_{\mathbf{N d}}(\mathbf{t})$ & $\left({ }^{87} \mathbf{S r} /{ }^{86} \mathbf{S r}\right)_{i}$ & $\mathbf{t}_{\text {DM1 }}(\mathbf{G a})$ & $\mathbf{t}_{\text {DM2 }}(\mathbf{G a})$ \\
\hline 14LP41 & 0.263 & $0.714994 \pm 11$ & 0.1193 & $0.511412 \pm 4$ & -4.04 & 0.705094898 & 2.79 & 2.63 \\
14LP42 & 0.494 & $0.720542 \pm 14$ & 0.1524 & $0.512271 \pm 5$ & 4.24 & 0.701962536 & 2.18 & 2.01 \\
14LP43 & 0.391 & $0.717897 \pm 15$ & 0.1182 & $0.511413 \pm 5$ & -3.76 & 0.703196637 & 2.76 & 2.61 \\
14LP44 & 0.183 & $0.713436 \pm 12$ & 0.1190 & $0.511392 \pm 6$ & -4.37 & 0.706543927 & 2.81 & 2.65 \\
14LP45 & 1.122 & $0.731517 \pm 10$ & 0.1592 & $0.512311 \pm 5$ & 3.27 & 0.689306833 & 2.34 & 2.06 \\
14LP46 & 0.257 & $0.718045 \pm 10$ & 0.1193 & $0.511417 \pm 8$ & -3.96 & 0.70836653 & 2.78 & 2.62 \\
14LP47 & 0.448 & $0.724754 \pm 19$ & 0.1444 & $0.512201 \pm 10$ & 4.94 & 0.707900517 & 2.08 & 1.97 \\
14LP52 & 1.112 & $0.732503 \pm 26$ & 0.1550 & $0.512316 \pm 7$ & 4.45 & 0.690671501 & 2.16 & 1.99 \\
14LP53 & 1.171 & $0.734906 \pm 14$ & 0.1504 & $0.512284 \pm 7$ & 5.03 & 0.690856575 & 2.08 & 1.96 \\
14LP54 & 0.879 & $0.728720 \pm 12$ & 0.1528 & $0.512304 \pm 5$ & 4.78 & 0.695672588 & 2.11 & 1.97 \\
\hline
\end{tabular}

Note: $\varepsilon_{N d}(t)=\left[\left({ }^{143} \mathrm{Nd} /{ }^{144} \mathrm{Nd}\right)_{\text {sample }} /\left({ }^{143} \mathrm{Nd} /{ }^{144} \mathrm{Nd}\right)_{\text {CHUR }}-1\right] \times 10000$. 
Table 6. Major-element (\%) and trace-element (ppm) compositions of k-feldspar granite porphyry from Baijiagou.

\begin{tabular}{|c|c|c|c|c|c|c|c|c|c|c|}
\hline sample & 14LP17 & 14LP18 & 14LP19 & 14LP20 & 14LP21 & 14LP22 & 14LP23 & 14LP24 & 14LP25 & 14LP26 \\
\hline $\mathrm{SiO}_{2}$ & 73.66 & 78.24 & 73.80 & 68.41 & 71.26 & 68.07 & 69.18 & 67.61 & 62.02 & 70.16 \\
\hline $\mathrm{TiO}_{2}$ & 0.56 & 0.55 & 0.59 & 0.55 & 0.52 & 0.59 & 0.67 & 0.56 & 0.71 & 0.60 \\
\hline $\mathrm{Al}_{2} \mathrm{O}_{3}$ & 7.59 & 6.96 & 8.86 & 13.48 & 7.41 & 12.03 & 12.54 & 11.37 & 11.47 & 11.87 \\
\hline $\mathrm{Fe}_{2} \mathrm{O}_{3}{ }^{\mathrm{T}}$ & 4.72 & 6.32 & 4.29 & 5.59 & 3.76 & 5.94 & 4.98 & 6.31 & 8.01 & 6.13 \\
\hline $\mathrm{MnO}$ & 0.11 & 0.11 & 0.09 & 0.09 & 0.09 & 0.10 & 0.09 & 0.15 & 0.10 & 0.13 \\
\hline $\mathrm{MgO}$ & 1.01 & 1.16 & 1.11 & 1.51 & 0.86 & 1.58 & 1.20 & 1.75 & 0.95 & 1.61 \\
\hline $\mathrm{CaO}$ & 4.10 & 1.53 & 2.55 & 0.33 & 6.11 & 1.21 & 0.48 & 1.60 & 4.34 & 1.05 \\
\hline $\mathrm{Na}_{2} \mathrm{O}$ & 2.67 & 2.06 & 1.72 & 2.38 & 1.88 & 2.05 & 2.15 & 2.72 & 2.56 & 3.82 \\
\hline $\mathrm{K}_{2} \mathrm{O}$ & 0.56 & 0.74 & 3.21 & 5.29 & 1.90 & 5.42 & 5.65 & 2.80 & 4.52 & 1.86 \\
\hline $\mathrm{P}_{2} \mathrm{O}_{5}$ & 0.11 & 0.10 & 0.11 & 0.11 & 0.10 & 0.11 & 0.13 & 0.10 & 0.15 & 0.11 \\
\hline LOI & 4.67 & 2.66 & 3.47 & 2.04 & 6.18 & 2.52 & 3.06 & 4.87 & 4.71 & 2.54 \\
\hline TOTAL & 99.76 & 100.43 & 99.80 & 99.78 & 100.07 & 99.62 & 100.13 & 99.84 & 99.54 & 99.88 \\
\hline $\mathrm{A} / \mathrm{CNK}$ & 0.61 & 1.00 & 0.81 & 1.32 & 0.46 & 1.05 & 1.19 & 1.09 & 0.67 & 1.16 \\
\hline $\mathrm{Mg}^{\#}$ & 33.3 & 30.0 & 37.6 & 38.6 & 34.8 & 38.3 & 36.0 & 39.3 & 21.7 & 38.0 \\
\hline $\mathrm{Li}$ & 13.0 & 20.7 & 13.4 & 18.6 & 19.0 & 17.7 & 18.3 & 21.3 & 11.5 & 20.7 \\
\hline $\mathrm{Be}$ & 1.87 & 1.95 & 1.57 & 2.64 & 1.76 & 2.60 & 1.80 & 2.03 & 1.64 & 1.85 \\
\hline $\mathrm{Sc}$ & 9.88 & 10.6 & 8.45 & 10.1 & 11.0 & 10.4 & 11.2 & 9.62 & 11.0 & 10.7 \\
\hline $\mathrm{V}$ & 8.06 & 9.50 & 7.58 & 10.3 & 9.30 & 13.1 & 10.7 & 6.60 & 10.3 & 9.39 \\
\hline $\mathrm{Cr}$ & 7.89 & 7.35 & 6.78 & 20.4 & 6.68 & 8.15 & 7.50 & 16.3 & 7.99 & 7.07 \\
\hline Co & 16.1 & 15.4 & 12.8 & 11.7 & 11.9 & 12.3 & 11.7 & 14.6 & 11.7 & 12.2 \\
\hline $\mathrm{Ni}$ & 5.08 & 6.82 & 3.76 & 16.9 & 3.99 & 5.07 & 3.42 & 10.2 & 3.82 & 3.77 \\
\hline $\mathrm{Cu}$ & 8.82 & 5.66 & 2.45 & 5.62 & 2.77 & 3.81 & 2.72 & 2.50 & 2.97 & 2.52 \\
\hline $\mathrm{Zn}$ & 121 & 133 & 126 & 156 & 98.8 & 127 & 144 & 215 & 112 & 196 \\
\hline $\mathrm{Ga}$ & 20.0 & 19.6 & 17.2 & 25.8 & 16.7 & 24.4 & 23.2 & 26.8 & 17.9 & 25.1 \\
\hline $\mathrm{Ge}$ & 1.66 & 1.85 & 1.24 & 1.39 & 1.26 & 1.13 & 1.16 & 1.48 & 1.32 & 1.24 \\
\hline $\mathrm{Rb}$ & 37.2 & 38.6 & 74.0 & 148 & 55.9 & 141 & 129 & 91.9 & 99.2 & 58.0 \\
\hline $\mathrm{Sr}$ & 51.9 & 44.2 & 49.3 & 64.9 & 63.6 & 48.8 & 34.2 & 45.7 & 57.3 & 45.1 \\
\hline $\mathrm{Y}$ & 88.2 & 80.7 & 79.9 & 81.8 & 88.1 & 79.6 & 84.3 & 78.8 & 122 & 78.1 \\
\hline $\mathrm{Zr}$ & 535 & 520 & 580 & 388 & 525 & 611 & 678 & 558 & 763 & 616 \\
\hline $\mathrm{Nb}$ & 25.2 & 24.5 & 25.9 & 27.1 & 23.2 & 28.2 & 31.1 & 25.6 & 33.8 & 27.3 \\
\hline Cs & 0.38 & 0.58 & 0.29 & 0.69 & 0.34 & 0.41 & 0.33 & 0.57 & 0.32 & 0.34 \\
\hline $\mathrm{Ba}$ & 114 & 132 & 1044 & 2738 & 857 & 1631 & 1061 & 510 & 1535 & 672 \\
\hline $\mathrm{La}$ & 211 & 251 & 82.9 & 101 & 91.8 & 24.7 & 63.2 & 120 & 133 & 91.3 \\
\hline $\mathrm{Ce}$ & 401 & 482 & 171 & 207 & 189 & 59.2 & 132 & 242 & 276 & 193 \\
\hline $\operatorname{Pr}$ & 49.6 & 59.3 & 21.1 & 25.0 & 23.3 & 7.88 & 16.4 & 30.4 & 34.3 & 23.3 \\
\hline $\mathrm{Nd}$ & 193 & 229 & 82.2 & 95.6 & 88.2 & 34.2 & 65.2 & 113 & 124 & 87.7 \\
\hline $\mathrm{Sm}$ & 31.3 & 36.3 & 17.4 & 17.6 & 16.7 & 9.19 & 13.5 & 21.3 & 22.9 & 15.9 \\
\hline $\mathrm{Eu}$ & 4.21 & 5.20 & 2.76 & 2.50 & 2.27 & 1.45 & 1.90 & 2.83 & 3.42 & 2.05 \\
\hline $\mathrm{Gd}$ & 22.9 & 27.2 & 15.6 & 14.9 & 14.7 & 9.98 & 11.9 & 17.0 & 21.8 & 13.0 \\
\hline $\mathrm{Tb}$ & 2.95 & 3.44 & 2.36 & 2.19 & 2.30 & 1.95 & 1.99 & 2.46 & 3.42 & 2.05 \\
\hline Dy & 16.6 & 17.8 & 14.1 & 13.7 & 14.8 & 13.4 & 13.5 & 14.5 & 21.5 & 13.0 \\
\hline Ho & 3.18 & 3.02 & 2.90 & 2.89 & 3.00 & 2.95 & 3.02 & 2.88 & 4.42 & 2.77 \\
\hline $\mathrm{Er}$ & 9.13 & 8.29 & 8.48 & 8.58 & 8.73 & 8.70 & 9.43 & 8.33 & 12.3 & 8.43 \\
\hline $\mathrm{Tm}$ & 1.31 & 1.19 & 1.27 & 1.27 & 1.31 & 1.31 & 1.47 & 1.23 & 1.75 & 1.28 \\
\hline $\mathrm{Yb}$ & 8.72 & 8.05 & 8.60 & 8.58 & 8.58 & 8.83 & 10.1 & 8.19 & 11.5 & 8.80 \\
\hline $\mathrm{Lu}$ & 1.28 & 1.18 & 1.28 & 1.28 & 1.24 & 1.31 & 1.50 & 1.20 & 1.68 & 1.33 \\
\hline $\mathrm{Hf}$ & 13.1 & 12.8 & 14.4 & 10.0 & 12.6 & 14.8 & 16.6 & 13.4 & 18.5 & 15.0 \\
\hline $\mathrm{Ta}$ & 1.34 & 1.31 & 1.48 & 1.43 & 1.24 & 1.51 & 1.70 & 1.36 & 1.82 & 1.43 \\
\hline $\mathrm{Pb}$ & 5.71 & 8.97 & 4.06 & 5.67 & 5.15 & 5.81 & 4.52 & 6.07 & 5.10 & 3.50 \\
\hline Th & 18.5 & 18.7 & 19.9 & 18.8 & 19.8 & 17.7 & 21.8 & 19.2 & 23.3 & 19.3 \\
\hline $\mathrm{U}$ & 4.83 & 3.14 & 4.25 & 5.60 & 3.17 & 3.16 & 3.81 & 3.82 & 5.84 & 4.61 \\
\hline$\delta E u$ & 0.48 & 0.51 & 0.51 & 0.47 & 0.44 & 0.46 & 0.46 & 0.45 & 0.47 & 0.44 \\
\hline
\end{tabular}

Note: $\mathrm{A} / \mathrm{CNK}=\left(\mathrm{Al}_{2} \mathrm{O}_{3} / 101.96\right) /\left[(\mathrm{CaO} / 56.08)+\left(\mathrm{Na}_{2} \mathrm{O} / 61.98\right)+\left(\mathrm{K}_{2} \mathrm{O} / 94.20\right)\right]$. 
(a)

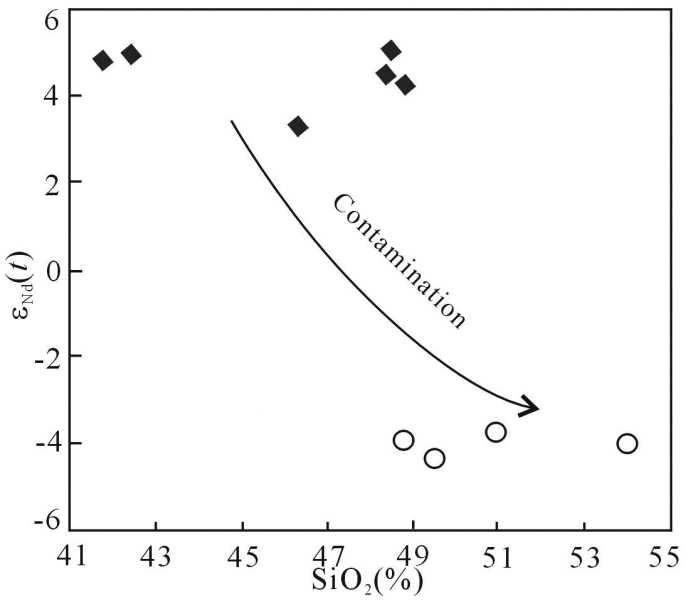

(b)

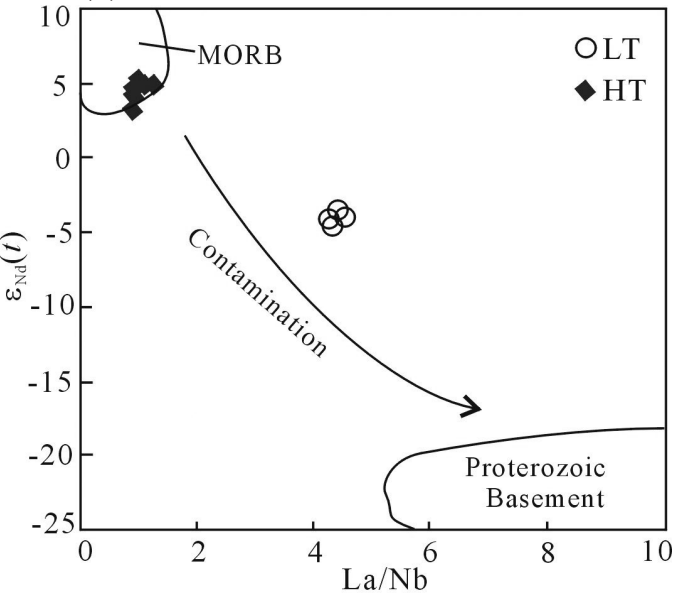

Fig. 11. $\varepsilon_{\mathrm{Nd}}(\mathrm{t})-\mathrm{SiO}_{2}(\mathrm{a})$ and $\varepsilon_{\mathrm{Nd}}(\mathrm{t})-\mathrm{La} / \mathrm{Nb}$ (b) diagram for Baijiagou diabase (after Wei and $\mathrm{Xu} 2013$ ).
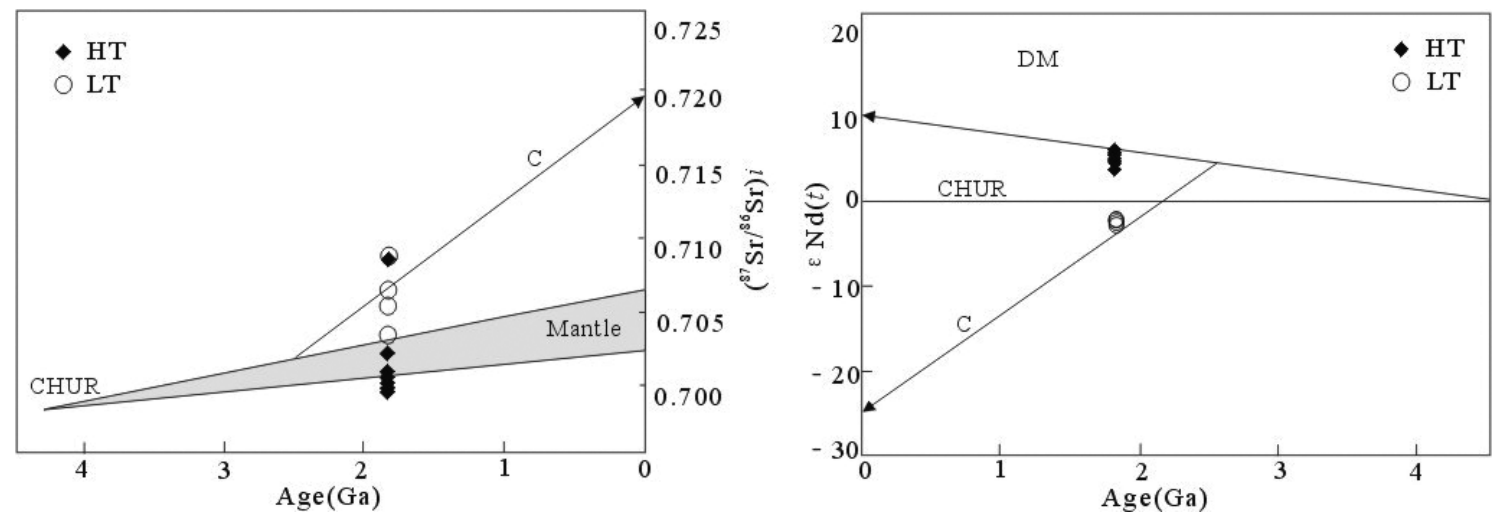

Fig. 12. $\left({ }^{87} \mathrm{Sr} /{ }^{86} \mathrm{Sr}\right)_{i}$-t and $\varepsilon_{\mathrm{Nd}}$-t diagram for Baijiagou diabase (after Han and Ma 2003).

$\mathrm{Sr}$ isotopes, the initial $\mathrm{Sr}, \mathrm{Nb}$ isotopes of the HT type diabase basically follow the mantle evolution line; the evolution of initial $\mathrm{Sr}, \mathrm{Nb}$ isotopes for $\mathrm{LT}$ type diabase is between the mantle and the crust, which is the result of crustal contamination.

\subsubsection{Crystal Fractionation}

Fractional crystallization of different minerals from parental magmas of the same composition will produce rocks with contrasting geochemistry and mineralogy. The crystallization of different minerals from parental magmas of the same composition can result from differences in pressure-temperature conditions. Figure 13a show that $\mathrm{MgO}$ is rough correlated with $\mathrm{Fe}_{2} \mathrm{O}_{3}{ }^{\mathrm{T}}$ for the LT type diabase, which is indicative of olivine fractionation. But the correlations are insignificant for the HT type diabase. No correlation or negative correlation between $\mathrm{CaO}$ and $\mathrm{MgO}$ for both $\mathrm{LT}$ and HT type diabase (Fig. 13b) suggests non fractionation of calcic pyroxene (e.g., diopside). The LT type shows positive correlations between $\mathrm{Sr}$ and $\mathrm{Al}_{2} \mathrm{O}_{3}$ (Fig. 13c), reflecting the crystallization of calcic plagioclase during the evolution of the LT diabase magma. The LT diabase also has significant negative $\mathrm{Eu}$ and $\mathrm{Sr}$ anomalies, consistent with plagioclase crystallization; no correlation between $\mathrm{Sr}$ and $\mathrm{Al}_{2} \mathrm{O}_{3}$ for the HT type indicates that fractionation of calcic plagioclase did not occur, consistent with the lack of Eu anomalies. Figure $13 \mathrm{~d}$ shows that the LT type diabase mainly formed by crystal fractionation.

\subsubsection{Source of the Parental Magma}

In a mid-ocean ridge basalt (MORB)-normalized multielement (spider) diagram (Fig. 9a), the diabase samples are enriched in $\mathrm{K}, \mathrm{Rb}, \mathrm{Ba}$, Th, and Ce relative to MORB, which is similar to continental basalts produced in an extensional setting (Pearce 1982; Dong et al. 1998; Kalsbeek et al. 2001). The LT type is characterized by depletions of $\mathrm{Nb}, \mathrm{Ta}$, and Ti relative to the $\mathrm{HT}$ type, and the $\mathrm{Th} / \mathrm{Nb}$ ratios of the $\mathrm{LT}$ and HT diabases are $0.30-0.29$ and $0.08-0.1$, respectively, 
(a)
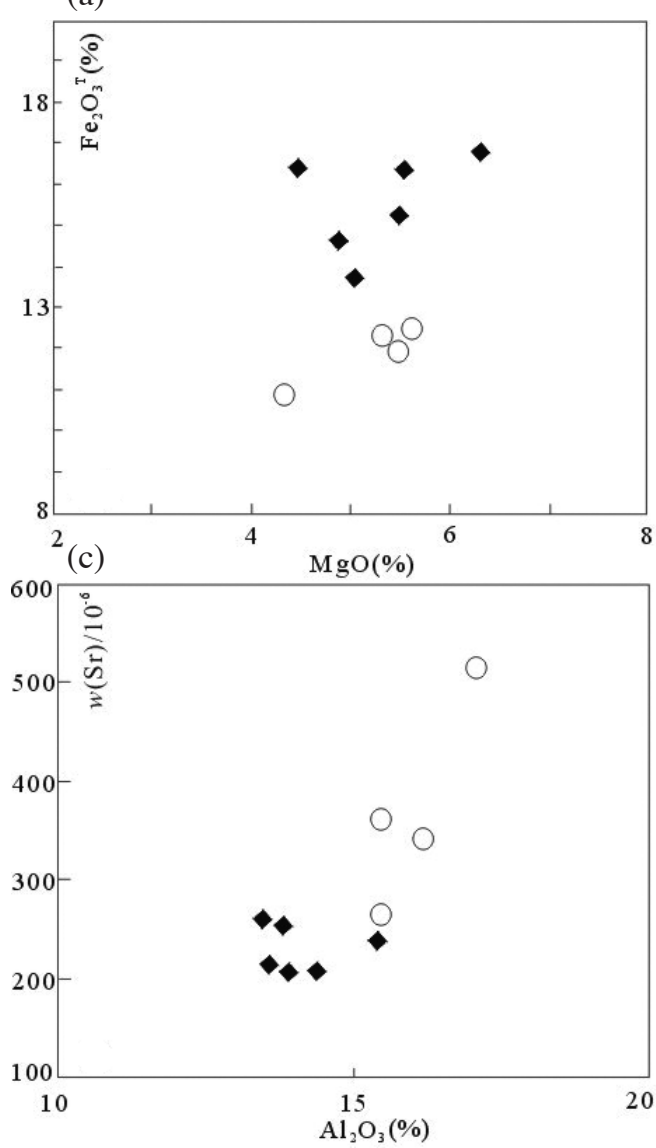

(b)
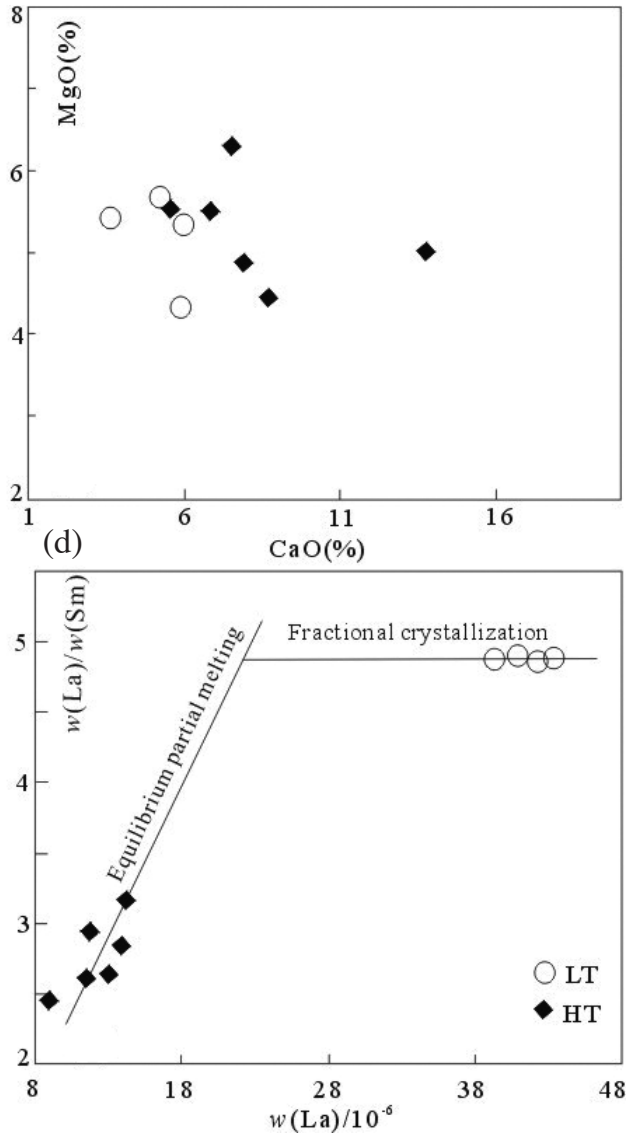

Fig. 13. Harker diagrams showing fractional crystallization trends for the Baijiagou diabase.

and their $\mathrm{Th} / \mathrm{Ta}$ ratios are $5.83-5.58$ and $1.33-1.65$, respectively. These ratios are similar to those of continental rift basalt (LT) and mantle plume basalt (HT), respectively (Wang et al. 2001; Sun et al. 2003). The chondrite-normalized REE patterns of the HT type are distinct from MORB and similar to ocean island basalt (OIB). The main difference between the HT type diabase and OIB is that the former is LILE enriched and has some continental characteristics. The HT type diabase is geochemically similar to HT basalts of the Emei Mounto igneous province (Xu and Chung 2001; Xiao et al. 2003; Wei and Xu 2013). These characteristics suggest that the HT type diabase may come from convective mantle. And the LT type diabase maybe derived from convective mantle and crust.

The $\mathrm{Sr}$ and $\mathrm{Nd}$ isotopic systems are commonly used as magma source region tracers. On a $\left({ }^{87} \mathrm{Sr} /{ }^{86} \mathrm{Sr}\right)_{i}$ - $\mathrm{t}$ and $\varepsilon_{\mathrm{Nd}} \mathrm{t}$ diagram (Fig. 12) the HT type diabase plot on the mantle evolution line, and the $T_{\mathrm{DM} 2}$ of the HT type $(1.96-2.06 \mathrm{Ga})$ is roughly near crystallizing age. But the LT type diabase plot between the mantle and the crust, which suggest that the rich end-member came from the ancient crust material. The $T_{\mathrm{DM} 2}$ of the LT type (2.61 - 2.65 Ga) can also confirm this.

The flat middle-heavy REE patterns of the LT diabase indicate derivation from a garnet-free source. The minimum pressure of garnet stability is $1.6-1.7 \mathrm{GPa}$ (Deng et al. 2009), meaning that the source of the LT diabase magma experienced a pressure of $<1.6 \mathrm{GPa}$ (i.e., $<56 \mathrm{~km}$ ), within the lithospheric mantle. In contrast, the HT diabase did not experience plagioclase crystallization (no negative $\mathrm{Eu}-\mathrm{Sr}$ anomalies), and its REE pattern (Figs. 9 and 10) indicates that its source was garnet-bearing. The garnet stability zone is generally at a depth of $>80 \mathrm{~km}$, meaning that the source of the HT diabase magma was at depths of $>80 \mathrm{~km}$ (Deng et al. 2009). Hence, the HT diabase magma may have been derived from a mantle plume or the asthenosphere.

Petrographic and geochemical data show that the granite porphyry located near the diabase is an A-type granite. The formation of A-type granite generally requires low pressures and water contents, and high temperatures. Partial melting experiments have demonstrated that A-type granites can be produced from the shallow continental crust at $\mathrm{P}<$ $0.8 \mathrm{GPa}$ and $\mathrm{T}>800^{\circ} \mathrm{C}$ (Zhang et al. 2010). It is thought that zircon saturation temperatures represent the near-liquidus temperatures of granitic rocks (Watson and Harrison 1983). Miller et al. (2003) calculated a series of zircon saturation temperatures and showed that there are perhaps two types 
of granites: "Hot granites" have $T_{\mathrm{Zr}}>800^{\circ} \mathrm{C}$, whereas "cold granites" have $T_{\mathrm{Zr}}<800^{\circ} \mathrm{C}$. The difference in the temperature estimates is attributed to the amount of inherited zircon, with the "hot granites" containing few inherited zircons. We calculated $T_{\mathrm{Zr}}$ for the Baijiagou granite porphyry using the following equation:

$$
\begin{aligned}
& T_{\mathrm{Zr}}\left({ }^{\circ} \mathrm{C}\right)= \\
& 12900 /[2.95+0.85 \mathrm{M}+\ln (496000 / \mathrm{Zr})]-273.15
\end{aligned}
$$

In this equation, $\mathrm{M}$ is the atomic fraction normalizing parameter, where $\mathrm{Si}+\mathrm{Al}+\mathrm{Fe}+\mathrm{Mg}+\mathrm{Ca}+\mathrm{Na}+\mathrm{K}+\mathrm{P}=$ 1 and $\mathrm{M}=(2 \mathrm{Ca}+\mathrm{K}+\mathrm{Na}) /(\mathrm{Si} \times \mathrm{Al})$. This equation yielded crystallization temperatures for the Baijiagou granite porphyry of ca. $880^{\circ} \mathrm{C}$. There are also no inherited zircons in the granite porphyry. Zircon saturation temperatures typically represent the lowest temperature of magmatic crystallization, and so the formation temperature of the Baigaogou granite was $>880^{\circ} \mathrm{C}$. According to the geothermal gradient and at $0.8 \mathrm{GPa}$ pressure, the temperature would be $<700^{\circ} \mathrm{C}$; however, with input of mantle heat the temperature at $30 \mathrm{~km}$ depth can reach $\sim 900^{\circ} \mathrm{C}$. Therefore, a thermal anomaly was involved in the formation of granite porphyry, perhaps provided by upwelling mantle.

The above discussion leads to the conclusion that the Paleoproterozoic diabase and granite porphyry formed in a continental rift environment, possibly an active rift caused by mantle plume activity. This conclusion is supported by $\mathrm{Th} / \mathrm{Hf}-\mathrm{Ta} / \mathrm{Hf}$ and $2 \mathrm{Nb}-\mathrm{Zr} / 4-\mathrm{Y}$ tectonic discrimination diagrams (Fig. 14).

Figure 15 shows a schematic depiction of the magmatic evolution of the Baijiagou region. The ascending mantle plume caused regional crustal uplift, extension, and thinning. At the same time, the high-temperature magmas from the mantle plume caused partial melting of the lower crust and formation of A-type granitic magma. The early mantle plume material mixed with crustal material during upwelling and the LT diabase magma formed. The LT diabase and A-type granite were formed at the same time. Later magmas
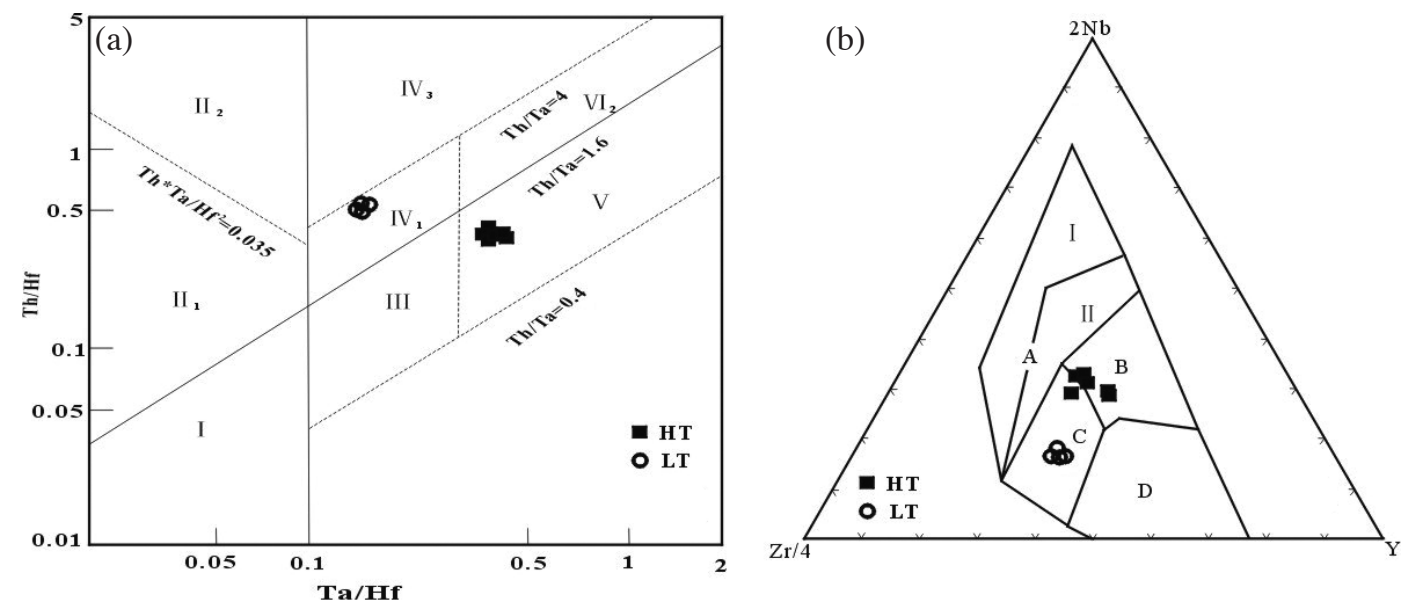

Fig. 14. Th/Hf-Ta/Hf and 2Nb-Zr/4-Y tectonic setting discrimination diagrams for basalts [(a) modified after Wang et al. 2001; (b) after Meschede 1986]. I: N-MORB; II: convergent plate margin basalt (II1: oceanic arc basalt; II2: continental island arc basalt); III: T-MORB, E-MORB; IV: continental intraplate basalt (IV1: continental rift valley or continental margin rift basalt; IV2: continental rift valley alkali basalt; IV3: continental extensional zone and incipient rift valley basalt); V: mantle plume basalt; A: intraplate alkali basalt; B: mantle plume oceanic ridge basalt; C: intraplate tholeiitic basalt; D: normal oceanic ridge basalt.

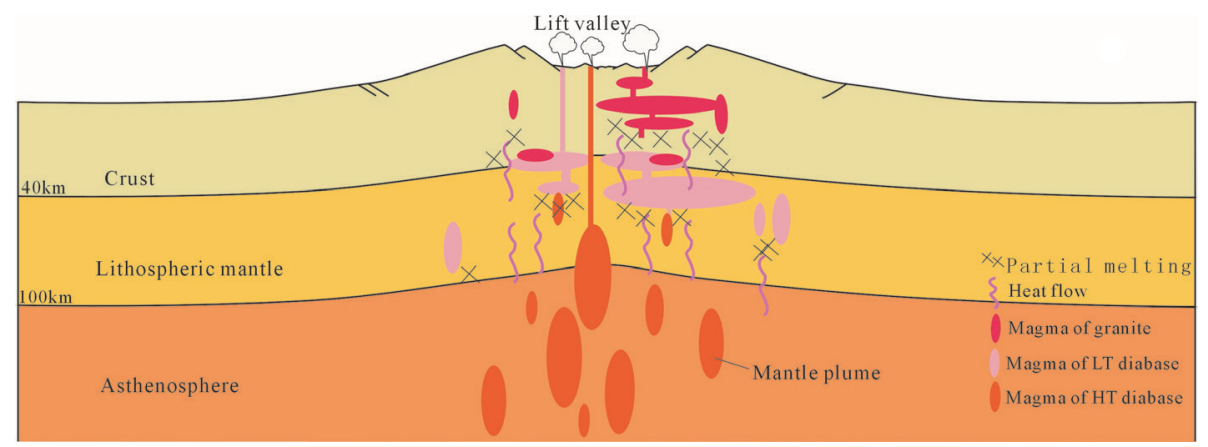

Fig. 15. Schematic diagram of the magma sources of the Baijiagou rocks (modified after Wilson 1989). 
were derived directly from the mantle plume and formed the HT diabase. Subsequently, the crust and lithosphere were further extended and formed a fully developed continental rift. Later tectonism, sedimentation, and erosion mean that the sedimentary strata of this Paleoproterozoic are now rarely exposed; however, the bimodal magmatism of the Baijiagou region provides direct evidence for the southward extension of the Helan aulacogen.

\subsection{Tectonic Implications}

Previous studies have examined the extensional tectonic events of the NCC and the formation of its aulacogens in the late Paleoproterozoic (Li et al. 2000; Zhai and Peng 2007; Zhao et al. 2007; Zhai et al. 2014; Gao et al. 2013). These extensional events produced a rift system in the NCC. E-W-trending rifts evolved into the Qinling-Qilian trough and the NNE- to NE-trending rifts (Helan, Xiong'er, and Yanliao rifts) evolved into aulacogens (Che et al. 2011). Previous studies on the Xiong'er and Yanliao aulacogens have suggested that extension was associated with breakaway of the NCC from the Columbia Supercontinent (Yang et al. 2005; Zhao et al. 2007; Cui et al. 2010), and may have been related to a mantle plume (Peng et al. 2005; Xu et al. 2007; Yang et al. 2019). Zhai (2004) and Zhai et al. (2014) provided evidence for mantle plume involvement, including: (1) large-scale mantle upwelling and uplift of the lower crust to the surface, accompanied by strong migmatization and meso-ductile deformation that exposed granulite-amphibolite-facies metamorphic rocks; (2) medium-pressure granulite- and amphibolite-facies retrograde metamorphism of high-pressure granulite dikes in the NCC at $1820-1800$ and 1790 - $1760 \mathrm{Ma}$, with isothermal or decreasing-T decompression P-T-t paths; (3) basement uplift following the rift events; and (4) rapid enrichment of ancient depleted mantle in the period from 2000 to $1900-1760 \mathrm{Ma}$. It can thus be inferred that mantle upwelling caused uplift of the NCC, which resulted in lithospheric thinning, partial melting, and the development of a rift system. Other studies have reached similar conclusions, and consider that the Xiong'er volcanic rocks and mafic dikes, anorthosites, alkaline granites, and rapakivi granites with ages of 1750 - 1680 Ma represent the mantle plume or break-up of the Columbia supercontinent (Peng et al. 2005, 2007; Hou et al. 2008; Hou 2012; Zhang et al. 2012). Xu et al. (2007) and Yang et al. (2019) argued that the Xiaoliangling volcanic rocks in the Luliang area are similar to the Xiong'er volcanic rocks in terms of lithology, geochemistry, and age, and speculated that their formation was also related to mantle plume activity.

Mantle plumes can produce significant, short-term environmental effects due to large volcanic eruptions, and longerterm effects on global tectonism, including: (1) regional crustal uplift and subsequent continent rifting; (2) the evolution and extinction of biota; and (3) regional and global changes in climate; however, such effects from an ancient Proterozoic mantle plume are difficult to identify (Xu and Qiu 2010). Therefore, identification of ancient mantle plumes relies on petrological and geochemical studies of igneous rocks. Our study area is located at the southwestern margin of the NCC, and connects the Qinling-Qilian and Helan troughs. The two types of diabase and granite porphyry present in this region formed at $1.8 \mathrm{Ga}$, and have geochemical features consistent with formation in a continental rift environment associated with a mantle plume. These rocks were produced during a period of rifting in the NCC that was linked to the break-up of the Columbia supercontinent.

\section{CONCLUSIONS}

(1) The crystallization age of the Baijiagou diabase is 1804 $\pm 21 \mathrm{Ma}(\mathrm{MSWD}=0.19$ ), which is therefore Paleoproterozoic in age.

(2) The diabase can be divided into LT and HT types.

(3) The diabase is associated with a coeval granite porphyry, and these collectively represent a Paleoproterozoic bimodal magmatic assemblage related to continental rifting and a mantle plume.

(4) The major $1.8 \mathrm{Ga}$ rifting event (Helan aulacogen) at the southwestern margin of the NCC, which may have been caused by a mantle plume, was associated with the break-up of the Columbia supercontinent.

Acknowledgements Financial support for this study was jointly provided by the MOST Special Fund from State Key Laboratory of Continental Dynamics, 201210133.

\section{REFERENCES}

Boynton, W. V., 1984: Cosmochemistry of the rare Earth elements: Meteorite studies. In: Henderson, P. (Ed.), Rare Earth Element Geochemistry: Developments in Geochemistry, Vol. 2, Elsevier, Amsterdam, 63-114, doi: 10.1016/B978-0-444-42148-7.50008-3. [Link]

Che, Z. C. and R. S. Wang, 1985: An investigation on Cenozoic volcanism in Weihe Basin. Journal of Northwest University, 49, 82-88.

Che, Z. C., J. H. Luo, and L. Liu, 2011: China and Its Adjacent Area Geotectonics, Science Press, Beijing, 26-32, 239-246.

Cui, M. L., B. L. Zhang, P. Peng, L. C. Zhang, X. L. Shen, Z. H. Guo, and X. F. Huang, 2010: Zircon/baddeleyite $\mathrm{U}-\mathrm{Pb}$ dating for the Paleo-proterozoic intermediateacid intrusive rocks in Xiaoshan Mountains, west of Henan Province and their constraints on the age of the Xiong'er Volcanic Province. Acta Petrologica Sinica, 26, 1541-1549.

Deng, J. F., Z. H. Luo, S. G. Su, X. X. Mo, B. S. Yu, X. Y. Lai, and H. W. Zhan, 2009: Yanshi chengyin gouzao 
huanjing yu chengkuang zuoyong. Geological Publishing House, Beijing, 32-40.

Dong, C. Y., S. J. Wang, G. Y. Liu, J. G. Wang, W. Wang, Z. Y. Song, and Y.S. Wan, 2010: Late Palaeoproterozoic crustal evolution of the North China Craton and formation time of the Jingshan Group: Constraints from SHRIMP U-Pb zircon dating of meta-intermediate-basic intrusive rocks in eastern Shandong Province. Acta Petrologica Sinica, 27, 1699-1706.

Dong, Y. P., D. W. Zhou, G. W. Zhang, and X. M. Liu, 1998: Geochemistry of the Caledonian basic volcanic rocks in the south margin of Qinling Orogenic belt and their tectonic implications. Geochimica, 27, 432-440.

Gao, L., X. Ding, Q. Cao, and C. Zhang, 2010: New Geological time scale of Late Precambrian in China and geochronology. Geology in China, 37, 1014-1020, doi: 10.3969/j.issn.1000-3657.2010.04.016. [Link]

Gao, S., J. Lin, and Y. Lu, 2013: Formation epoch and its geological implications of Paleoprotozoic A-ype granite in Shizuizi of Jingyuan County, Ningxia Province. Acta Petrologica Sinica, 29, 2676-2684.

Geng, Y., C. Yang, B. Song, and Y. Wan, 2004: Post-orogenic granites with an age of $1800 \mathrm{Ma}$ in Luliang area, North China Craton: Constraints from isotopic geochronology and geochemistry. Geological Journal of China Universities, 10, 477-487.

Geng, Y., Q. Shen, and L. Ren, 2010: Late Neoarchean to Early Paleoproterozoic magrnatic events and tectonothermal systems in the North China Craton. Acta Petrologica Sinica, 26, 1945-1966.

Günther, D. and B. Hattendorf, 2005: Solid sample analysis using laser ablation inductively coupled plasma mass spectrometry. TrAC, Trends in Analytical Chemistry, 24, 255-265, doi: 10.1016/j.trac.2004.11.017. [Link]

Han, B., L. Zhang, Y. Wang, and B. Song, 2007: Enriched mantle source for Paleoproterozoic high $\mathrm{Mg}$ and low Ti-P mafic dykes in central part of the North China Craton: Constrains from zircon $\mathrm{Hf}$ isotopic compositions. Acta Petrologica Sinica, 23, 277-284.

Han, Y. W. and Z. D. Ma, 2003: Geochemistry, Geological Publishing House, Beijing, 224-228.

Hou, G., 2012: The Mafic Dyke Swarms in the North China Craton, Science Press, Beijing.

Hou, G., M. Santosh, X. Qian, G. S. Lister, and J. Li, 2008: Configuration of the Late Paleoproterozoic supercontinent Columbia: Insights from radiating mafic dyke swarms. Gondwana Res., 14, 395-409, doi: 10.1016/j. gr.2008.01.010. [Link]

Hou, G., C. Wang, and L. Li, 2010: Magnetic fabric evidences for the late Paleoproterozoic mafic dyke swarm emplacement, southern margin of the North China Craton. Acta Petrologica Sinica, 26, 318-324.

Hu, G., J. Hu, W. Chen, and T. Zhao, 2010: Geochemistry and tectonic setting of the $1.78 \mathrm{Ga}$ mafic dyke swarms in the Mt. Zhongtiao and Mt. Song areas, the southern margin of the North China Craton. Acta Petrologica Sinica, 26, 1563-1576.

Hua, H. and S. Qiu, 2001: Three medoproterozoic stromatolite assemblages in the Helan MT., Ningxia and the their biostratigraphic siginificance. Journal of Stratigraphy, 25, 307-311.

Irvine, T. N. and W. R. A. Baragar, 1971: A guide to the chemical classification of the common volcanic rocks. Can. J. Earth Sci., 8, 523-548, doi: 10.1139/e71-055. [Link]

Jahn, B.-M. and K. C. Condie, 1995: Evolution of the Kaapvaal Craton as viewed from geochemical and Sm$\mathrm{Nd}$ isotopic analyses of intracratonic pelites. Geochim. Cosmochim. Acta, 59, 2239-2258, doi: 10.1016/00167037(95)00103-7. [Link]

Jiang, N., J. Guo, M. Zhai, and S. Zhang, 2010: 2.7Ga crust growth in the North China craton. Precambrian Res., 179, 37-49, doi: 10.1016/j.precamres.2010.02.010. [Link]

Jiang, N., J. Guo, and M. Zhai, 2011: Nature and origin of the Wenquan granite: Implications for the provenance of Proterozoic A-type granites in the North China Craton. J. Asian Earth Sci., 42, 76-82, doi: 10.1016/j. jseaes.2011.04.010. [Link]

Kalsbeek, F., H. F. Jepsen, and A. P. Nutman, 2001: From source migmatites to plutons: Tracking the origin of ca. $435 \mathrm{Ma}$ S-type granites in the East Greenland Caledonian orogen. Lithos, 57, 1-21, doi: 10.1016/S00244937(00)00071-2. [Link]

Li, J., X. Qian, G. Hou, S. Liu, and J. Chen, 2000: Late Palaeoproterozoic to early Mesoproterozoic tectonic framework and major tectono-thermal episodes of North China: New interpretation of "Luliang Orogeny". Earth Science-Journal of China University of Geosciences, 25, 15-20.

Li, J., G. Hou, and X. Qian, 2001: Single zircon U-Pb age of the initial Mesoproterozoic basic dike swarms in Hengshan Mountain andits implication for the tectonic evolution of the North China Craton. Geological Review, 47, 235-238, doi: 10.16509/j.georeview.2001.03.003. [Link]

Li, Z., X. Liu, Y. Dong, and Z. Xiao, 2013: Geochemistry and zircon $\mathrm{U}-\mathrm{Pb}$ age of the Paleoproterozoic syn-collisional granites in Helanshan region and its geological significance. Acta Petrologica Sinica, 29, 2405-2415.

Liang, X. R., G. J. Wei, X. H. Li, and Y. Liu, 2003: Precise measurement of ${ }^{143} \mathrm{Nd} /{ }^{144} \mathrm{Nd}$ and $\mathrm{Sm} / \mathrm{Nd}$ ratios using multiple-collectors inductively coupled plasma-mass spectrometer (MC-ICPMS). Geochimica, 32, 91-96.

Liu, X., 2011: Chronological, petrological and geochemical characteristics of the Paleo-Mesoproterozoic alkali-rich intrusive rocks along the southern part of the North China Craton. Master Thesis, Chinese Academy 
of Geological Sciences, Beijing, 56-59.

Lu, S., C. Yang, H. Li, and H. Li, 2002: A group of rifting events in the terminal Paleoproterozoic in the North China Craton. Gondwana Res., 5, 123-131, doi: 10.1016/s1342-937x(05)70896-0. [Link]

Ludwig, K., 2001: Users Manual for Isoplot/Ex Rev. 2.49, Berkeley Geochronology Centre Special Publication, 1-56.

Meschede, M., 1986: A method of discriminating between different types of mid-ocean ridge basalts and continental tholeiites with the Nb-Zr-Y diagram. Chem. Geol., 56, 207-218, doi: 10.1016/0009-2541(86)90004-5. [Link]

Miller, C. F., S. M. McDowell, and R. W. Mapes, 2003: Hot and cold granites? Implications of zircon saturation temperatures and preservation of inheritance. Geology, 31, 529-532, doi: 10.1130/0091-7613(2003)031<0529:hacgio $>2.0 . c o ; 2$. [Link]

Pearce, J. A., 1982: Trace element characteristics of lavas from destructive plate boundaries. In: Thorpe, R. S. (Ed.), Orogenic Andesites and Related Rocks, Wiley, Chichester, England, 528-548.

Peng, P., M. Zhai, H. Zhang, T. Zhao, and Z. Ni, 2004: Geochemistry and geological significance of the 1.8 Ga mafic dyke swarms in the North China Craton: An example from the juncture of Shanxi, Hebei and Inner Mongolia. Acta Petrologica Sinica, 20, 439-456.

Peng, P., M. Zhai, H. Zhang, and J. Guo, 2005: Geochronological constraints on the Paleoproterozoic evolution of the North China craton: SHRIMP zircon ages of different types of mafic dikes. Int. Geol. Rev., 47, 492508, doi: 10.2747/0020-6814.47.5.492. [Link]

Peng, P., M.-G. Zhai, J.-H. Guo, T. Kusky, and T.-P. Zhao, 2007: Nature of mantle source contributions and crystal differentiation in the petrogenesis of the $1.78 \mathrm{Ga}$ mafic dykes in the central North China craton. Gondwana Res., 12, 29-46, doi: 10.1016/j.gr.2006.10.022. [Link]

Peng, P., M. Zhai, R. E. Ernst, J. Guo, F. Liu, and B. Hu, 2008: A $1.78 \mathrm{Ga}$ large igneous province in the North China craton: The Xiong'er Volcanic Province and the North China dyke swarm. Lithos, 101, 260-280, doi: 10.1016/j.lithos.2007.07.006. [Link]

Peng, P., M.-G. Zhai, Q. Li, F. Wu, Q. Hou, Z. Li, T. Li, and Y. Zhang, 2011: Neoproterozoic ( 900Ma) Sariwon sills in North Korea: Geochronology, geochemistry and implications for the evolution of the south-eastern margin of the North China Craton. Gondwana Res., 20, 243-254, doi: 10.1016/j.gr.2010.12.011. [Link]

Ren, F., H. Li, Y. Yin, S. Li, S. Ding, Z. Chen, 2000: The upper chronological limit of Xionger Group's volcanic rock series, and its geological significance. Progress in Precambrian Research, 23, 140-146.

Rubatto, D., 2001: Zircon trace element geochemistry: Par- titioning with garnet and the link between U-Pb ages and metamorphism. Chem. Geol., 184, 123-138, doi: 10.1016/S0009-2541(01)00355-2. [Link]

Sun, S., Y. Wang, and C. Zhang, 2003: Discrimination of the tectonic settings of basalts by $\mathrm{Th}, \mathrm{Nb}$ and $\mathrm{Zr}$. Geological Review, 49, 40-47, doi: 10.3321/j.issn:03715736.2003.01.006. [Link]

Wang, C., X. D. Ma, and Z. R. Lang, 2012a: Zircon SHRIMP U-Pb dating of granite porphyry at Shizuizi in southern section of Liupanshan and its significance. Ningxia Engineering Technology, 11, 335-337.

Wang, H., Z. Xiang, and F. Zhao, 2012b: The alkaline plutons ineastern part of Guyang County, Inner Mongolia: Geochronology, petrogenesis and tectonic implications. Acta Petrologica Sinica, 28, 2843-2854.

Wang, T., 1995: Evolutionary characteristics of geological structure and oil-gas accumulation in Shanxi-Shaanxi area. Journal of Geology \& Mineral Resources of North China, 10, 283-398.

Wang, W., S. Liu, M. Santosh, X. Bai, Q. Li, P. Yang, and R. Guo, 2013: Zircon U-Pb-Hf isotopes and wholerock geochemistry of granitoid gneisses in the Jianping gneissic terrane, Western Liaoning Province: Constraints on the Neoarchean crustal evolution of the North China Craton. Precambrian Res., 224, 184-221, doi: 10.1016/j.precamres.2012.09.019. [Link]

Wang, X.-L., S.-Y. Jiang, and B.-Z. Dai, 2010: Melting of enriched Archean subcontinental lithospheric mantle: Evidence from the ca. 1760Ma volcanic rocks of the Xiong'er Group, southern margin of the North China Craton. Precambrian Res., 182, 204-216, doi: 10.1016/j.precamres.2010.08.007. [Link]

Wang, Y., C. Zhang, and S. Xiu, 2001: Th/Hf-Ta/Hf identification of tectonic setting of basalts. Acta Petrologica Sinica, 17, 413-421.

Watson, E. B. and T. M. Harrison, 1983: Zircon saturation revisited: Temperature and composition effects in a variety of crustal magma types. Earth Planet. Sci. Lett., 64, 295-304, doi: 10.1016/0012-821x(83)90211-x. [Link]

Weaver, B. L., 1991: The origin of ocean island basalt endmember compositions: Trace element and isotopic constraints. Earth Planet. Sci. Lett., 104, 381-397, doi: 10.1016/0012-821x(91)90217-6. [Link]

Wei, G., X. Liang, X. Li, and Y. Liu, 2002: Precise measurement of Sr isotopic composition of liquid and solid base using (LP) MC-ICPMS. Geochimica, 31, 295-299.

Wei, X. and Y. Xu, 2013: Petrogenesis of the mafic dykes from Bachu and implications for the magma evolution of the Tarim large igneous province, NW China. Acta Petrologica Sinica, 29, 3323-3335.

Whalen, J. B., K. L. Currie, and B. W. Chappell, 1987: Atype granites: Geochemical characteristics, discrimination and petrogenesis. Contrib. Mineral. Petrol., 95, 
407-419, doi: 10.1007/BF00402202. [Link]

Wiedenbeck, M., P. Allé, F. Corfu, W. L. Griffin, M. Meier, F. Oberli, A. Von Quadt, J. C. Roddick, and W. Spiegel, 1995: Three natural zircon standards for U-Th- $\mathrm{Pb}$, Lu-Hf, trace element and ree analyses. Geostandards Newsletter, 19, 1-23, doi: 10.1111/j.1751-908X.1995. tb00147.x. [Link]

Wiedenbeck, M., J. M. Hanchar, W. H. Peck, P. Sylvester, J. Valley, M. Whitehouse, A. Kronz, Y. Morishita, L. Nasdala, J. Fiebig, I. Franchi, J.-P. Girard, R. C. Greenwood, R. Hinton, N. Kita, P. R. D. Mason, M. Norman, M. Ogasawara, P. M. Piccoli, D. Rhede, H. Satoh, B. Schulz-Dobrick, O. Skår, M. Spicuzza, K. Terada, A. Tindle, S. Togashi, T. Vennemann, Q. Xie, and Y.-F. Zheng, 2004: Further characterisation of the 91500 zircon crystal. Geostand. Geoanal. Res., 28, 9-39, doi: 10.1111/j.1751-908X.2004.tb01041.x. [Link]

Wilson, M., 1989: Igneous Petrogenesis, Springer, Dordrecht, 466 pp, doi: 10.1007/978-1-4020-6788-4. [Link]

Xiao, L., Y. Xu, H. Mei, and S. Sha, 2003: Geochemistry of Emeishan flood basalts at Binchuan area, SW China: Rock type and temporal evolution. Chinese Journal of Geology, 38, 478-494.

Xiao, P., W. You, C. Xie, P. Li, and S. Bai, 2011: LA-ICPMS U-Pb detrital zircon geochronology of alumina-rich gneiss of the Helanshan complex-group in the northern segment of Helanshan Mountains and regional comparison. Geological Bulletin of China, 30, 26-36.

Xu, H., H. Zhao, J. Luo, J. Cheng, J. You, and S. Wang, 2014: Paleoproterozoic granite and its tectonic significances in southwestern margin of North China Plate, Baojiashan section in Longxian County. Geological Review, 60, 1284-1296, doi: 10.16509/j.georeview.2014.06.007. [Link]

Xu, X. and J. Qiu, 2010: Igneous Petrology, Science Press, Beijing, 316-320.

Xu, Y. and S. L. Chung, 2001: The Emeishan large igneous province: Evidence for mantle plume activity and melting conditions. Geochemica, 30, 1-9.

Xu, Y., T. Zhao, P. Peng, M. Zhai, L. Qi, and Y. Luo, 2007: Geochemical characteristics and geological significance of the paleoproterozoic volcanic rocks from the Xiaoliangling formation in the Luliang area, Shanxi province. Acta Petrologica Sinica, 23, 1123-1132.

Yang, J., F. Wu, X. Liu, and L. Xie, 2005: Zircon U-Pb ages and $\mathrm{Hf}$ isotopes and their geological significance of the Miyun rapakivi granites from Beijing, China. Acta Petrologica Sinica, 21, 1633-1644.

Yang, S., P. Peng, Z. Qin, X. Wang, C. Wang, J. Zhang, and T. Zhao, 2019: Genetic relationship between 1780 Ma dykes and coeval volcanics in the Lvliang area, North China. Precambrian Res., 329, 232-246, doi: 10.1016/j.precamres.2017.10.004. [Link]

You, J., J. Luo, J. Cheng, S. Wang, H. Xu, and H. Zhao, 2014: Paleoproterozoic granite porphyry in southwestern margin of North China Craton and its geological significance. Geological Journal of China Universities, 20, 368-377, doi: 10.16108/j.issn10067493.2014.03.020. [Link]

Zhai, M.-G., 2004: 2.1 1.7 Ga geological event group and its geotectonic significance. Acta Petrologica Sinica, 20, 1343-1354.

Zhai, M.-G. and P. Peng, 2007: Paleoproterozoic events in the North China Craton. Acta Petrologica Sinica, 23, 2665-2682.

Zhai, M.-G. and M. Santosh, 2011: The early Precambrian odyssey of the North China Craton: A synoptic overview. Gondwana Res., 20, 6-25, doi: 10.1016/j. gr.2011.02.005. [Link]

Zhai, M.-G. and M. Santosh, 2013: Metallogeny of the North China Craton: Link with secular changes in the evolving Earth. Gondwana Res., 24, 275-297, doi: 10.1016/j.gr.2013.02.007. [Link]

Zhai, M.-G., B. Hu, P. Peng, and T. Zhao, 2014: Meso-Neoproterozoic magmatic events and multi-stage rifting in the NCC. Earth Science Frontiers, 21, 100-119.

Zhang, Q., W. Jin, C. Li, and Y. Wang, 2010: Revisiting the new classification of granitic rocks based on wholerock $\mathrm{Sr}$ and $\mathrm{Yb}$ contents: Index. Acta Petrologica Sinica, 26, 985-1015.

Zhang, S., S. Liu, Y. Zhao, J. Yang, B. Song, and X. Liu, 2007: The 1.75-1.68Ga anorthosite-mangerite-alkali granitoid-rapakivi granite suite from the northern North China Craton: Magmatism related to a Paleoproterozoic orogen. Precambrian Res., 155, 287-312, doi: 10.1016/j.precamres.2007.02.008. [Link]

Zhang, S., Z.-X. Li, D. A. D. Evans, H. Wu, H. Li, and J. Dong, 2012: Pre-Rodinia supercontinent Nuna shaping up: A global synthesis with new paleomagnetic results from North China. Earth Planet. Sci. Lett., 353-354, 145-155, doi: 10.1016/j.eps1.2012.07.034. [Link]

Zhao, G., M. Sun, S. A. Wilde, and L. Sanzhong, 2005: Late Archean to Paleoproterozoic evolution of the North China Craton: Key issues revisited. Precambrian Res., 136, 177-202, doi: 10.1016/j.precamres.2004.10.002. [Link]

Zhao, G., S. A. Wilde, M. Sun, S. Li, X. Li, and J. Zhang, 2008: SHRIMP U-Pb zircon ages of granitoid rocks in the Lüliang Complex: Implications for the accretion and evolution of the Trans-North China Orogen. Precambrian Res., 160, 213-226, doi: 10.1016/j.precamres.2007.07.004. [Link]

Zhao, T., M. Zhai, B. Xia, H. Li, Y. Zhang, and Y. Wan, 2004: Xiong'er Group SHRIMP zircon geochronology: On the development of the North China Craton cover initial time constraints. Chinese Science Bulletin, 
49, 2342-2349, doi: 10.1360/04wd0065. [Link]

Zhao, T., Y. Xu, and M. Zhai, 2007: Petrogenesis and Tectonic Setting of the Paleoproterozoic Xiong'er Group in the Southern Part of the North China Craton: A Review. Geological Journal of China Universities, 13, 191-206, doi: 10.16108/j.issn1006-7493.2007.02.005. [Link]

Zhao, T., X. Deng, G. Hu, Y. Zhou, P. Peng, and M. Zhai, 2015: The Paleoproterozoic-Mesoproterozoic boundary of the North China Craton and the related geological issues: A review. Acta Petrologica Sinica, 31, 1495-1508.

Zhao, T.-P. and M.-F. Zhou, 2009: Geochemical constraints on the tectonic setting of Paleoproterozoic A-type granites in the southern margin of the North China Cra- ton. J. Asian Earth Sci., 36, 183-195, doi: 10.1016/j. jseaes.2009.05.005. [Link]

Zhao, T.-P., W. Chen, and M.-F. Zhou, 2009: Geochemical and Nd-Hf isotopic constraints on the origin of the $1.74-G a$ Damiao anorthosite complex, North China Craton. Lithos, 113, 673-690, doi: 10.1016/j. lithos.2009.07.002. [Link]

Zhou, X., G. Zhao, and Y. Geng, 2010: Helanshan high pressure pressure politic granulite: Petrologic evidence for collision event in the western block of the North China Craton. Acta Petrologica Sinica, 26, 2113-2121.

Zhu, R., Y. Xu, G. Zhu, H. Zhang, Q. Xia, and T. Zheng, 2012: Destruction of the North China Craton. Sci. China Earth Sci., 55, 1565-1587, doi: 10.1007/s11430012-4516-y. [Link] 